\title{
Articles
}

\section{Be the First Investor to Eat Crabs in North Korea: Tips for Bilateral Investment Treaties}

\author{
Xuechan Ma | ORCID: 0000-0003-2768-1160 \\ Leiden University, Leiden, The Netherlands \\ xuechan.ma@fao.org
}

Anran Zhang | ORCID: 0000-0003-3103-9269

Erasmus University, Rotterdam, The Netherlands

ryanzhanganran@outlook.com

\begin{abstract}
As the last economic frontier in Northeast Asia, North Korea is a promising land but at the same time a risky land for foreign investment. The 'dual-track' policy of advancing both the political stability and economic development promoted by the present leader of North Korea, Kim Jong-un, has prompted the outside world to speculate that he is determined to gradually open the doors to the economy of North Korea to attract foreign investment as initial capital to mobilise domestic economic growth. By conducting a systemic and comparative analysis of the existing bilateral investment treaties (BITs) signed by North Korea in the Kim Jong-il era, this article has put forward eight tips that can better prepare those daredevils who are interested in seizing the future opportunity to invest in North Korea in the present Kim Jong-un era. It is predicted that denuclearisation will bring a new era for North Korean BITs.
\end{abstract}




\section{Keywords}

bilateral investment treaties - Security Council sanctions - disputed marine areas investor-State dispute settlement - inter-State dispute settlement - Korean War

\section{Introduction}

The Democratic People's Republic of Korea (DPRK), also known as North Korea, is located in the northern part of the Korean Peninsula in East Asia. Since its establishment, North Korea has been ruled by the three-generation lineage from the first leader, Kim Il-Sung (in office between 1948 and 1994), to his son, Kim Jong-il (in office between 1994 and 2011), then to his grandson, Kim Jong-un (in office from 2011 to now). The present leader, namely Kim Jong-un, has set out comprehensive measures to realise his purported 'dualtrack' policy of advancing both the political stability, especially through the nuclear program, and economic development since he came into power in 2011. ${ }^{1}$ Consequently, the previously forbidden word 'reform' began to appear in North Korea's official discourse, ${ }^{2}$ and the establishment of dozens of special economic zones (SEZs) with ostensibly foreign-friendly regulations has prompted the outside world to speculate that North Korea was determined to gradually open its doors to attract foreign investment as initial capital to mobilise domestic economic growth. ${ }^{3}$ Almost all these SEZs are located far from residential areas but close to borders, which not only stabilises the national security but also suits to attract foreign investment from its neighbouring countries

1 Ruediger Frank, 'North Korea's Economic Policy in 2018 and Beyond: Reforms Inevitable, Delays Possible' (38 North, 8 August 2018) <www.38north.org/2018/o8/rfranko8o818/>. Heesun Wee, 'How Kim Jong Un Wants to Develop His Economy and Secure His Regime' (CNBC, 11 June 2018) <www.cnbc.com/2018/o6/11/how-kim-jong-un-wants-to-develop-his -economy-and-secure-his-regime.html>. Hank Yoreh, 'Kim Jong-un Announces Switch to Economic Development' (Hankyoreh, 23 April 2018) <http://english.hani.co.kr/arti/english _edition/e_northkorea/841715.html $>$ all accessed 17 February 2021.

2 Marcus Noland, 'North Korea: Sanctions, Engagement and Strategic Reorientation' (2019) 14 Asian Economic Policy Review 189, 194.

3 Andray Abrahamian and Curtis Melvin, 'North Korea's Special Economic Zones: Plans vs Progress' (38 North, 23 November 2015) <www.38north.org/reports/2015/11/nk-sez-plans -vs-progress/>. Anna Isaac, 'Hidden Trillions: What if North Korea's Economy Opened Up?' (The Telegraph, 12 June 2018) <www.telegraph.co.uk/business/2018/o6/12/hidden-trillions -north-koreas-economy-came-shadows/>. Prableen Bajpai, 'How the North Korea Economy Works' (Investopedia, 26 October 2018) <www.investopedia.com/articles/investing/o13015/ how-north-korea-economy-works.asp\#>. 'Koreas Make Nuclear Pledge After Historic Summit' (BBC, 27 April 2018) <www.bbc.com/news/world-asia-43921385> all accessed 17 February 2021. 
such as China, Japan, Russia, and South Korea. Despite these positive signals, 'to be the first ones to eat crabs' (a Chinese idiom meaning 'people who are willing to take dangerous and risky chances'), foreign investors might remain concerned about the challenges and risks that they might encounter with.

North Korea is the last economic frontier in Northeast Asia. ${ }^{4}$ However, a series of sanctions imposed by the United Nations Security Council (UNSC) since 2006 constitutes a significant obstacle to North Korea's strategic opening of its economy. Even if these sanctions can be lifted as a result of denuclearisation, North Korea's domestic legal systems may remain a big concern that discourages foreign investment. North Korea has a right to decide which type of foreign investment is eligible to enter into its territory, subject to considerations such as political stability and national security, and to formalise relevant rules and processes in its domestic laws and institutions, including provisions about legal protection and tax benefits to incentivise foreign investment. Apart from domestic legislation and institutions, international legal systems, especially bilateral investment treaties (BIT s), are essential to guaranteeing foreign investors obtain fair treatment and sufficient protection and to providing a certain degree of safeguard so as to increase the confidence of foreign investors. In light of this, this article starts with a discussion of the UNSC sanctions and North Korea's domestic legal frameworks in relation to foreign investment (Section 2) in order to set the scene for a systemic analysis of the existing BITs involving North Korea (Section 3). Such a systemic analysis of North Korean BIT s has been little explored in literature, and this article seeks to fill this gap by exposing potential legal problems contained in the current design of these BIT s and proposing practical recommendations (Section 4). This article, being purely academic research and holding a neutral position, seeks to offer interested countries reflections on their future BIT negotiations with North Korea and to provide investment tips for foreign investors.

A significant obstacle to North Korea's strategic opening of its economy comes from outside the country. The UNSC has adopted a series of sanctions since 2006 with the aim of forcing North Korea to give up nuclear and missile programs in the exercise of its power under Chapter VII of the UN Charter to

4 Kim Jaewon and Mit Suru Obe, 'An Economically Focused North Korea Would Rely on Foreign Capital' (Nikkei Asian Review, 7 June 2018) <https://asia.nikkei.com/Politics/Trump -Kim-Summit/An-economically-focused-North-Korea-would-rely-on-foreign-capital> accessed 17 February 2021. 
maintain or restore international peace and security threatened by North Korea's nuclear testing and ballistic missile launching activities. ${ }^{5}$ These sanctions include, for example, prohibiting or limiting exports of military supplies, luxury goods, crude oil and refined petroleum products to North Korea, banning North Korea's exports of coal, iron, lead, food and agricultural products, machinery and electrical equipment, banning joint ventures, imposing sanctions on money transfers to shut North Korea out of the international financial system, and banning North Korean nationals from working abroad (see Table 1). There have been questions about the effectiveness of such UNSC sanctions. For example, Jeong looked into available trade data and concluded that UNSC resolution 1718 was ineffective in decreasing North Korea's imports of luxury goods, which had indeed increased from USD 135 million in 2006 to USD 304 million in $2017 \cdot{ }^{6}$ Nevertheless, as Noland rightly pointed out, these sanctions are comprehensive in the sense of covering about 9o percent of North Korea's trade and constraining investment and financial transactions, despite documented sophisticated sanctions evasion efforts and lax enforcement by some UN member countries. ${ }^{7}$

Sanctions are not without costs. A major cost of these sanctions, in Frank's view, is a discouragement of 'marketization and intensified contacts with the outside world' and the possibility of destroying 'the seeds of hope for a normalization of North Korea that is the precondition for a sustainable, indigenous, long-term solution of a multitude of issues surrounding that country' ${ }^{8}$ In fact, as UNSC sanctions have been extended beyond military and nuclear development and luxury goods to include more comprehensive restrictions about North Korea's access to the international monetary system and trade since 2013, North Korea's foreign direct investment (FDI) inflows had experienced a sharp drop from USD 102 million in 2014 to USD 26 million in 2019, as estimated in the 2020 World Investment Report issued by the United Nations Conference on Trade and Development (UNCTAD), ${ }^{9}$ despite its legal and institutional changes intended to promote foreign investor confidence especially in the past decade as discussed below. Therefore, it is fair to say that these sanctions must be lifted before North Korea can enjoy real economic progress through foreign investment where BIT s become relevant.

5 Charter of the United Nations (signed 26 June 1945, entered into force 4 October 1945) UNTS 16, ch VII, art 39 .

6 Hyung-Gon Jeong, 'United Nations Sanctions on North Korea's Luxury Goods Imports: Impact and Implications' (2019) 14(2) Asian Economic Policy Review 214, 226.

7 Noland (n 2) 192.

8 Ruediger Frank, 'The Political Economy of Sanctions Against North Korea' (2006) 30(3) Asian Perspective $5,21$.

9 UNCTAD, 'World Investment Report 2020' (2020) 239, annex table 1. 
Progress on denuclearisation negotiations since 2018 seemed to give rise to some optimism, which consisted of three rounds of inter-Korean summits (on 27 April, 26 May, and 18-20 September 2018, respectively) and two rounds of United States-North Korea summits (on 12 June 2018, and 27-28 February 2019, respectively) as well as a trilateral meeting among North Korea, South Korea and the United States (on 30 June 2019). ${ }^{10}$ In the Panmunjom Declaration for Peace, Prosperity and Unification of the Korean Peninsula ('Panmunjom Declaration'), adopted at the first inter-Korean summit on 27 April 2018, North Korea and South Korea agreed on 'the common goal of realising, through complete denuclearisation, a nuclear-free Korean peninsula." ${ }^{11}$ The 12 June 2018 United States-North Korea joint statement reaffirmed North Korea's commitment to 'complete denuclearisation of the Korean Peninsula.' ${ }^{2}$ This joint statement was seen as a prelude to the economic opening of North Korea. ${ }^{13}$ The ongoing denuclearisation talks seem to shed light on the ultimate lifting of the international sanctions so far as North Korea keeps its commitment. In fact, China and Russia proposed a draft UNSC resolution in December 2019 that would relax sanctions posed upon North Korea, although this proposal was later stymied by the United States. ${ }^{14}$

Even if these sanctions can be lifted, North Korea's domestic legislation and institutions may remain a big concern that discourages foreign investment. The North Korean government designated the Ministry of Foreign Economic Relations as the responsible institute for dealing with foreign investment

10 According to a recent perception survey conducted by the Korea Institute for National Unification (KINU) on 200 professionals (in the fields of political science, economics, North Korean studies, and international relations in academia, public and private research institutes, and the media, among others), $36 \%$ predicted the 'partial denuclearization of North Korea and the concurrent development of the United States-North Korea and inter-Korean relations' in the next 10 years. See Sung-yoon Chung and others, 'Perception Survey of Experts on the Environment for Promoting Denuclearization and Peace on the Korean Peninsula' (KINU, 202O) <http://repo.kinu.or.kr/bitstream/2015 .oak/11501/1/CO2O-10\%28e\%29.pdf > accessed 17 February 2021.

11 Panmunjom Declaration for Peace, Prosperity and Unification of the Korean Peninsula (adopted on 27 April 2019) art 3.4.

12 Joint Statement of President Donald J Trump of the United States of America and Chairman Kim Jong-un of the Democratic People's Republic of Korea at the Singapore Summit (12 June 2018) <www.whitehouse.gov/briefings-statements/joint-statement -president-donald-j-trump-united-states-america-chairman-kim-jong-un-democratic -peoples-republic-korea-singapore-summit> accessed 17 February 2021.

13 Shannon van Sant, 'Investors Eager for Economic Opening of North Korea' (NPR, 12 June 2018) <www.npr.org/2018/06/12/61910o379/investors-eager-for-economic-opening -of-north-korea?t=1543930355478> accessed 17 February 2021.

14 Michelle Nichols, 'Russia, China to Hold More UN Talks on Lifting North Korea Sanctions: Diplomats' (Reuters, 2o December 2019) <www.reuters.com/article/us-northkorea-usa -un-idUSKBNıYXoLD $>$ accessed 17 February 2021. 


$\begin{array}{llll}\text { UNSC } & \text { Trigger } & \text { Date of Resolution } & \text { Sanctions }\end{array}$

\section{Resolutions}

\begin{tabular}{ll} 
Resolution & $\begin{array}{l}\text { Nuclear test on } \\
\text { 1718 }\end{array}$ \\
\hline
\end{tabular}

Resolution Nuclear test on

$1874 \quad 25$ May 2009

Resolution Ballistic missile launch

2087

on 12 December 2012

$\begin{array}{ll}\text { Resolution } & \text { Nuclear test on } \\ 2094 & \text { 12 February } 2013\end{array}$

Resolution Nuclear test on

2270

6 January 2016

Resolution

2321

Nuclear test on 9

September 2016

Resolution Ballistic missile

2371 launches on 3 and

28 July 2017
14 October 2006

Prohibiting the export of some

military supplies and luxury goods to North Korea.

12 June 2009

Empowering member States to inspect ships and destroy any cargo suspected of concerning the nuclear weapons program.

22 January 2013 Clarifying a State's right to seize and destroy cargo suspected of heading to or from North Korea for military research and development.

7 March 2013

Imposing sanctions on money transfers with the aim of shutting North Korea out of the international financial system. 2 March $2016 \quad$ Banning North Korea's exports of gold, vanadium, titanium, rare earth metals, coal and iron.

3o November 2016

Capping North Korea's coal exports; and banning its exports of copper, nickel, zinc, and silver.

5 August 2017

Banning North Korea's exports of coal, iron, lead, and seafood; imposing new restrictions on North Korea's Foreign Trade Bank; and prohibiting any increase in the number of North Koreans working abroad. 
TABLE 1 Security Council Sanctions Against North Korea (cont.)

$\begin{array}{llll}\text { UNSC } & \text { Trigger } & \text { Date of Resolution } & \text { Sanctions } \\ \text { Resolutions } & & \end{array}$

$\begin{array}{lll}\text { Resolution } & \text { Nuclear test on } 2 & \text { 11 September } \\ \mathbf{2 3 7 5} & \text { September } 2017 & 2017\end{array}$

Resolution Ballistic missile launch on 22 December 2017 28 November 2017
Limiting North Korea's imports of crude oil and refined petro- leum product; banning joint ventures, North Korea's textile exports, natural gas condensate and liquid imports; and ban- ning North Korean nationals from working abroad.
Limiting North Korea's imports of crude oil and refined petro- leum product; banning North Korea's exports of food and agricultural products, machin- ery and electrical equipment; calling for repatriation of all North Korean nationals earn- ing income abroad within 24 months; and authorising mem- ber states to seize and inspect any vessel in their territorial waters found to be illicitly pro- viding oil or other prohibited products to North Korea.

\footnotetext{
NOTE: UNSC Res 1718 (14 October 2006) UN Doc S/RES/1718; UNSC Res 1874 (12 June 20o9) UN Doc S/ RES/1874 (2009); UNSC Res 2087 (22 January 2013) UN Doc S/RES/2087; UNSC Res 2094 (7 March 2013) UN Doc S/RES/2094; UNSC Res 2270 (2 March 2016) UN Doc S/RES/2270; UNSC Res 2321 (30 November 2016) UN Doc S/RES/2321; UNSC Res 2371 (5 August 2017) UN Doc S/RES/2371; UNSC Res 2375 (11 September 2017) UN Doc S/RES/2375 (2017); UNSC Res 2397 (22 December 2017) UN Doc S/RES/2397. SOURCE: AUTHOR COMPILATION BASED ON UN DOCUMENTS CITED
}

matters (since 2014) and enacted a set of laws and regulations on foreign investment, including the Foreign Investment Law as the basic law and relevant legislation applicable to SEZs..$^{15}$ Overall, such domestic legislation covers

15 For more details, see Ministry of Commerce of the People's Republic of China, 'Guide for Foreign Investment Cooperation Countries (Regions) - North Korea' (in Chinese, 2017). 
various aspects of foreign investment such as foreign exchange, taxation, land lease, labour relations, company registration, bankruptcy and other issues, but legislation is still lacking on some important matters including mergers and acquisitions, anti-monopoly, build-operate-transfer and public-private partnerships contracts that involve foreign investment.

Apart from legislative loopholes, there is also a yawning gap between laws and implementation in reality. What has been seen is that foreign investment in North Korea can sometimes become vulnerable to deteriorating inter-State relations despite the existence of applicable domestic laws. An illustrative example is the Kaesong Industrial Zone (KIZ), an SEZ located 6 miles north of the Korean Demilitarized Zone and 37 miles from downtown Seoul. The KIZ was also the only SEZ that North Korea allowed a foreign government to retain a certain degree of control by selecting mangers of the administrative agency. ${ }^{16}$ Attracted by high-profit margins due to low wages and the excellent location (close to Seoul as one of the most lucrative consumer markets in the region), 124 South Korean companies were operating in the KIZ by the end of 2015, employing a total of 53,000 North Korean workers. ${ }^{17}$ Despite the 2002 KIZ Law and its implementing regulations, the access from the South Korea side to the KIZ had been restricted at times of inter-Korean tension. For instance, in February 2016, the South Korea government announced the temporal closure of the KIZ and the recall of all staff, partly as a protest to North Korea's nuclear test in January that year. In response to this, North Korea announced to freeze all South Korean assets and equipment in the KIZ, which South Korea claimed to be illegal. With the peace talks starting in 2018, North Korea and South Korea agreed to set up an inter-Korean liaison office in the KIZ, but North Korea blew up this office in June 2020 as its relation with South Korea deteriorated.

In case of disputes, North Korea's domestic laws or contracts with foreign investors usually do provide dispute settlement mechanisms. However, the judicial system in North Korea is criticised as lacking independence, ${ }^{18}$ and in practice, negotiations facilitated by governments sometimes seem to play a more prominent role than other means. In August 2012, a Chinese company, Haicheng Xiyang Group, which made a 36 -million-euro investment in a venture processing iron-ore powder in North Korea, openly accused the North Korean government of corruption, fraud and violation of its own investment

16 Jeehye You, 'Legislative Reform of the Kaesong Industrial Complex in North Korea' (2011) 29 Pacific Basin L J 36, 44.

17 Ministry of Commerce of the People's Republic of China (n 16) 53.

18 Patricia Goedde, 'Update: Overview of the North Korean Legal System and Legal Research' (GlobaLex, 2011) <http://www.nyulawglobal.org/globalex/North_Korea1.htm> accessed 17 February 2021. 
laws, after the latter unilaterally terminated the investment contract and expelled all Chinese employees. ${ }^{19}$ This appears to be the only case of failed investment by Chinese companies in North Korea that has been reported in Chinese media. The North Korean government publicly refuted this accusation and claimed that the Chinese company was responsible for breaching the contract signed with a North Korean company, Fengling. This refutation, according to commentators, was a rare move, probably to prevent the incident from hindering foreign investment. ${ }^{20}$ Regardless of which side had actually breached the contract, this dispute had not been submitted to any administrative or judicial settlement procedures. In an interview, without explaining details, the owner of the Chinese company mentioned that Chinese personnel was not allowed to go to the North Korean International Trade Arbitration Commission (NKITAC) without the accompaniment of personnel from the North Korean partner. ${ }^{21}$ According to the North Korea Foreign Economic Arbitration Law, a party may initiate an arbitration against another party by sending a request to NKITAC in relation to foreign investment disputes, provided that there is an arbitration clause in the investment contract or a compromis after the dispute arises. ${ }^{22}$ The available information in the public domain was insufficient to tell whether such an arbitration clause or compromis existed or not in this dispute. Negotiations, facilitated by officials from the Chinese embassy in North Korea and from the North Korean government, took place between the Chinese company and the North Korean counterpart, to discuss a compensation plan after the contract termination. It was reported that the North Korean side agreed to pay compensation of EUR 30 million, but whether the Chinese company had eventually received the payment is unclear. ${ }^{23}$

Perhaps to reverse its controversial image of politicalising foreign investment, the North Korean government has made some efforts in improving its domestic legislation on foreign investment at least since 2012. For instance, the Rason SEZ is the first and largest SEZ in North Korea and borders China and Russia with easily accessible harbours. There was a single law regulating

19 Che Tan, 'Liaoning's Richest Man's Broken Dream in North Korea: 36-Million-Euro Investment Gone for Nothing' (Sohu, 12 October 2012) (in Chinese) <https://business .sohu.com/20121012/n354723449.shtml > accessed 17 February 2021.

20 'North Korea Central News Agency Refuted a Chinese Company's Accusation of Fraud' (People's Daily Online, 6 September 2012) (in Chinese) <http://finance.people.com .cn/n/2012/o9o6/c1004-18932867.html> accessed 17 February 2021.

21 Tan (n 20).

22 North Korea Foreign Economic Arbitration Law (adopted on 21 July 1999) art 5 (in Chinese) <www.zcmyw.com/cn/gycx/oF7720102175243.html > accessed ${ }_{17}$ February 2021.

23 'North Korea Blasts Chinese Company in Failed Deal' (Reuters, 5 September 2012) <www .nytimes.com/2012/o9/o6/business/global/north-korea-blasts-chinese-company-in -failed-deal.html> accessed 17 February 2021. 
foreign investment within the Rason SEZ between 1993 and 2012 that outlined the basic provisions such as customs duties, currency and finance, preferential treatments and dispute settlement. North Korea realised the need of a more comprehensive and delicate legal framework with detailed guidance and subsequently adopted a new Rason SEZ Law in 2016 and a total of at least 18 regulations to implement this law. ${ }^{24}$ Of course, there are still many areas for improvement in North Korea's domestic legal framework. It is also under this premise that the protection of foreign investment provided under BITs with North Korea becomes particularly relevant and important.

A Systemic Analysis of Existing BITs

So far, North Korea has signed 24 BIT s with different countries between 1996 to 2008 , all of which were concluded in the Kim Jong-il era. ${ }^{25}$ A North Korean BIT usually remains in force for a period of ten years after it has entered into force and will continue in force unless either Contracting State gives notice of the termination to the other Contracting State one year before the expiration. This article studies 13 BITs signed between North Korea and other respective countries that have available English versions (see Table 2). In general, these BITs start with definitions of core terms such as 'investor', 'investment' and 'returns', and encapsulate key clauses comprising (i) territorial scope, (ii) substantive protection, (iii) expropriation and compensation, and (iv) dispute settlement

24 These 18 implementing regulations are: Regulation of Operation or the Management Committee, Regulation of Establishment and Operation of Businesses, Regulation of Development, Regulation of Labor Regulations for Foreign-Invested Businesses, Regulation of Traffic Regulations, Regulation for the for the People's Security, Regulation of Financial Management of Foreign-invested Businesses, Accounting Regulation for Foreign-Invested Businesses, Audit Regulation for Foreign-Invested Businesses, Tax Regulations, Regulation on Administration of Tax Collection, Regulation on Real Estate, Regulation on the Protection of the Environment, Quarantine Regulations, Regulation on Fines, Regulation of Customs, Regulation of Entrance and Stay of Foreigners, and Regulation of Processing Trade. See Yeobin Yoon and Philipp Kopp, 'Overview of Legislation Development in Rason SEZ, DPRK' (Hanns Seidel Foundation / North Korean Economic Watch, 5 April 2017).

25 North Korea signed BITs with Bangladesh, Belarus, Bulgaria, Cambodia, China, Czech Republic, Denmark, Egypt, Indonesia, Islamic Republic of Iran, Italy, the Former Yugoslav Republic of Macedonia, Malaysia, Mali, Mongolia, Romania, Russian Federation, Serbia, Singapore, Slovakia, Switzerland, Syrian Arab Republic, Thailand, and Vietnam. The first BIT was signed with Denmark on 10 September 1996 (entered into force on 25 December 1997), and the last BIT was signed with Singapore on 2 December 2008 (entered into force on 18 March 2009). 
mechanisms. This article will examine each of these four key clauses contained in 13 studied BITs in turn.

\subsection{Territorial Scope}

All the studied BITs contain a provision defining the applicable territorial scope. With respect to North Korea, the territory over which such BITs shall apply is usually defined as below:

the territorial land, territorial waters, exclusive economic maritime zone and continental shelf over which it exercises sovereign rights or jurisdiction in accordance with its national law and international law. ${ }^{26}$

Accordingly, the applicable territorial scope should encompass both the land and marine areas subject to North Korea's sovereignty or jurisdiction. Marine areas include territorial seas, the exclusive economic zone (EEZ) and continental shelf. A coastal State enjoys full sovereignty over territorial seas and shall respect other States' right of innocent passage. In respect of EEZs and continental shelves, a coastal State enjoys specific sovereign rights, which are less than full sovereignty and mostly limited to the utilisation and conservation of marine natural resources.

Given the existence of a maritime boundary dispute between North Korea and South Korea in the Yellow Sea, ${ }^{27}$ a question naturally arising is whether the territorial scope of a BIT signed by North Korea should cover the contested maritime areas that North Korea claims to be under its sovereignty or jurisdiction. This question will become highly relevant if North Korea authorises a foreign investor to explore or exploit marine natural resources in the contested Yellow Sea in the future, the odds of which is indeed high due to North Korea's increasing demands for resources for economic development. ${ }^{28}$ The Energy

26 The Agreement between the Government of the Republic of Singapore and the Government of the Democratic People's Republic of Korea on the Promotion and Protection of Investments (Singapore-North Korea BIT) art 1.4.

27 Jon M Van Dyke, Mark J Valencia, and Jenny Miller Garmendia, 'The North/South Korea Boundary Dispute in the Yellow (West) Sea' (2003) 27 Marine Policy 143, 143.

28 It is important to note that though the North Korea Constitution stipulates that foreign investment is encouraged in special economic zones, which do not cover maritime areas at the moment, its Foreign Investment Law (FIL) promulgated in 1992 allows foreign investment throughout the territory of the whole country. Therefore, in theory, foreign investment respecting marine areas of North Korea is also protected by FIL. See The Socialist Constitution of the Democratic People's Republic of Korea (2019) art 37, and Foreign Investment Law of North Korea (1992) arts 1-2. The current constitution, which was approved in 1972, has replaced the 1948 constitution and has been amended and 


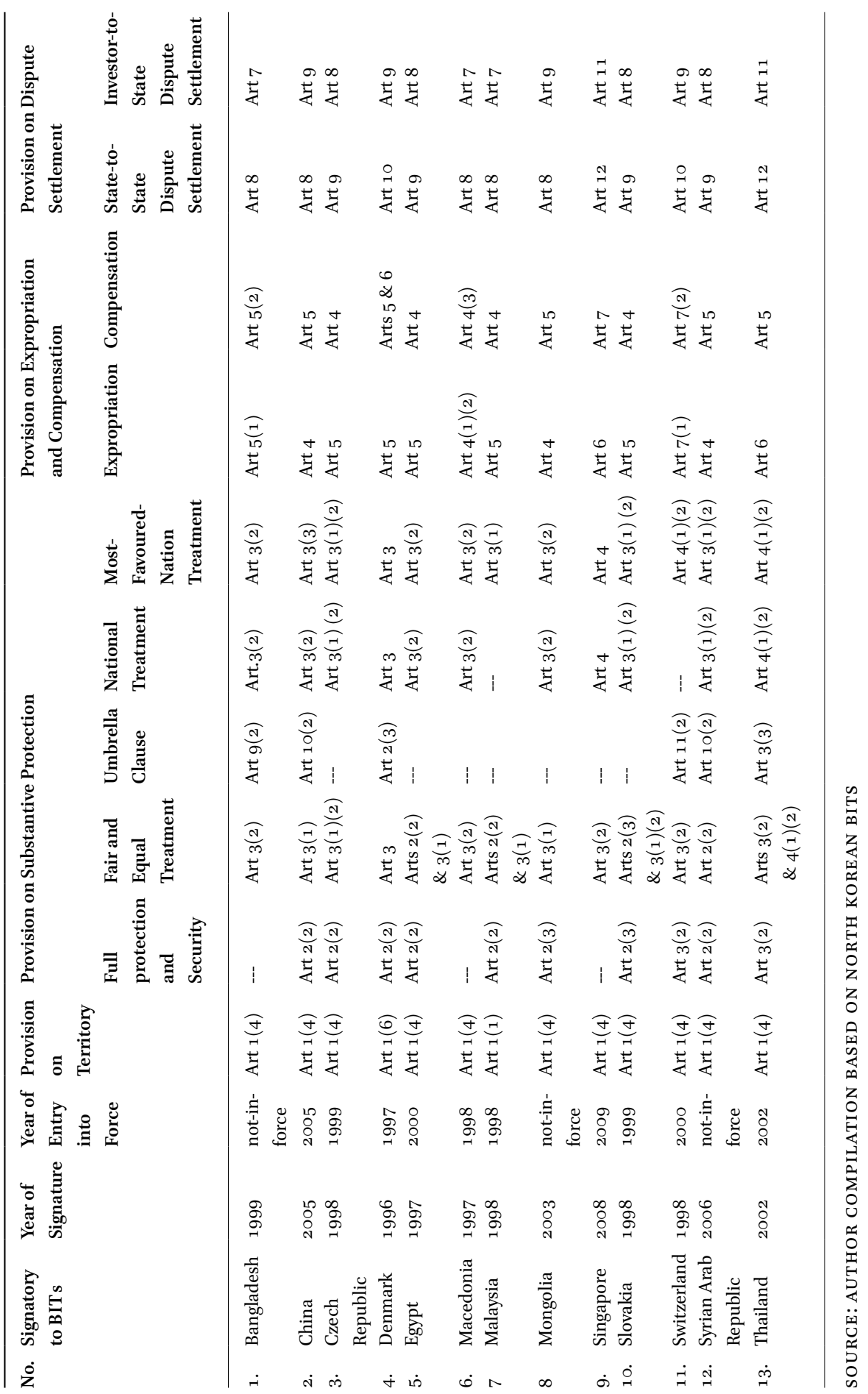


Information Administration (EIA) of the US reported that North Korea had no proven oil reserves or petroleum and other liquids production as of July $2015 .{ }^{29}$ With increasing demands for resources caused by economic development in the future, North Korea may turn its eyes to the Yellow Sea, which is rich in oil and gas potential..$^{30}$ In light of this, imagine if an investor-State dispute between such a foreign investor and North Korea arises and is submitted to a competent judicial body based on a relevant BIT. One jurisdiction ratione loci question will arise as to whether or not the judicial body has the jurisdiction to trial this dispute.

Before addressing this question, it is necessary to briefly introduce the contested marine areas in the Yellow Sea. The Korean War Armistice Agreement signed in 1953 was designed to 'ensure a complete cessation of hostilities and of all acts of armed force in Korea until a final peaceful settlement is achieved'. ${ }^{31}$ This agreement draws a military demarcation line (MDL) and requests both sides to withdraw $2 \mathrm{~km}$ from this line to establish a demilitarised zone (DMZ). ${ }^{32}$ Both the MDL and DMZ only apply to the land territory and do not extend to adjacent marine areas. Subsequently, the US-led United Nations Command (UNC) unilaterally drew a maritime demarcation line in the Yellow Sea in 1965 , namely the North Limit Line (NLL), in order to prohibit the vessels of the UNC from sailing north of the NLL without special permission. ${ }^{33}$ The NLL crosses waters presumed to be under uncontested North Korean sovereignty in at least two places. ${ }^{34}$ It is important to note that 3 nautical miles (M) were the recognised limit for territorial seas at the time of the designation of the NLL, but the law has changed since then, and now the accepted limit for

supplemented in 1998, 2009, 2012, 2013, 2016 and twice in 2019; see <www.lawandnorth korea.com/lawsblog/socialist-constitution-2019> accessed 17 February 2021.

29 'North Korea Has "Excellent" Oil and Gas Potential' (The Maritime Executive, 20 November 2015) <www.maritime-executive.com/article/north-korea-has-excellent -oil-and-gas-potential> accessed 17 February 2021.

30 Haiqi Zhang, 'Oil and Gas Exploration and Development in the Yellow Sea' <www.wilso ncenter.org/sites/default/files/media/documents/publication/Zhang_Hai_Qi.pdf>. Also see Cui Ning, 'Large Oil Reserves Found in Bohai Bay' (Chinadaily, 23 December 2004) $<$ www.chinadaily.com.cn/english/doc/2004-12/23/content_402814.htm> both accessed 17 February 2021.

31 Preamble of the Korean War Armistice Agreement (signed on 27 July 1953).

32 ibid art 1.1.

33 Central Intelligence Agency Directorate of Intelligence, 'The West Coast Korean Island' (January 1974) <https://digitalarchive.wilsoncenter.org/document/114023> para 4. ibid. 
territorial seas shall be $12 \mathrm{M} .{ }^{35}$ The NLL is only $8 \mathrm{M}(15 \mathrm{~km})$ from the coast of North Korea and leaves very little ocean space for it. South Korea endorses the NLL as the demarcation line for the time being. North Korea does not recognise the validity of the NLL and claims a distinct maritime MDL running well to the south of the NLL (see Figure 1), which approximates an equidistance line between the coasts of North Korea and South Korea and neglects the five small South Korean islands. ${ }^{36}$ To that effect, South Korea and North Korea have overlapping maritime claims with regard to the Yellow Sea.

According to Articles 3, 57 and 76(1) of the United Nations Convention on the Law of the Sea (UNCLOS), a coastal State has the right to claim a territorial sea with a breadth not exceeding $12 \mathrm{M}$, an EEZ not exceeding $200 \mathrm{M}$ and a continental shelf at least out to $200 \mathrm{M} .{ }^{37}$ Though North Korea is not a party to UNCLOS, Articles 3, 57 and 76(1) of UNCLOS have been widely accepted as customary international law, thus binding upon non-party States including North Korea. ${ }^{38}$ The NLL endorsed by South Korea measures only about $8 \mathrm{M}(15$ $\mathrm{km}$ ) from the coast of North Korea, thereby apparently incompatible with North Korea's right to claim a 12-M territorial sea along its coast under customary international law. Whether the MDL (approximating an equidistance line between the coasts of North Korea and South Korea) claimed by North Korea accords with international law needs further discussion. Articles 74 and 83 of UNCLOS required an equitable solution without specifying the delimitation method to be applied. ${ }^{39}$ In Maritime Delimitation in the Black Sea, built on the evolution of the jurisprudence on maritime delimitation, the International Court of Justice (ICJ) articulated a three-stage methodology, namely the equidistance-relevant circumstances-disproportion test method ${ }^{40}$ which is seen as established judicial practice unless there are compelling reasons. ${ }^{41}$ The first step of the

35 United Nations Convention on the Law of the Sea (adopted 10 December 1982, entered into force 16 November 1994) 1833 UNTS 396 (The UN Convention on the Law of the Sea) art 3 .

$3^{6}$ Van Dyke, Valencia and Garmendia (n 27).

37 The UN Convention on the Law of the Sea (n 35) arts 3, 57, 76.1.

38 Robin Rolf Churchill and Alan Vaughan Lowe, The Law of the Sea (3rd edn, Manchester UP 1999) 148.

39 Dispute Concerning Delimitation of the Maritime Boundary Between Bangladesh and Myanmar in the Bay of Bengal (Bangladesh / Myanmar) no 16, Judgment (14 March 2012) ITLOS Reports 2012, para 225.

40 Maritime Delimitation in the Black Sea (Romania v Ukraine) (Judgement) [2009] ICJ Rep 61, para 116.

41 Dispute Concerning Delimitation of the Maritime Boundary Between Bangladesh and Myanmar in the Bay of Bengal (Bangladesh / Myanmar) no 16, Joint Declaration of Judges Nelson, Chandrasekhara Rao and Cot (14 March 2012) 134-35. 


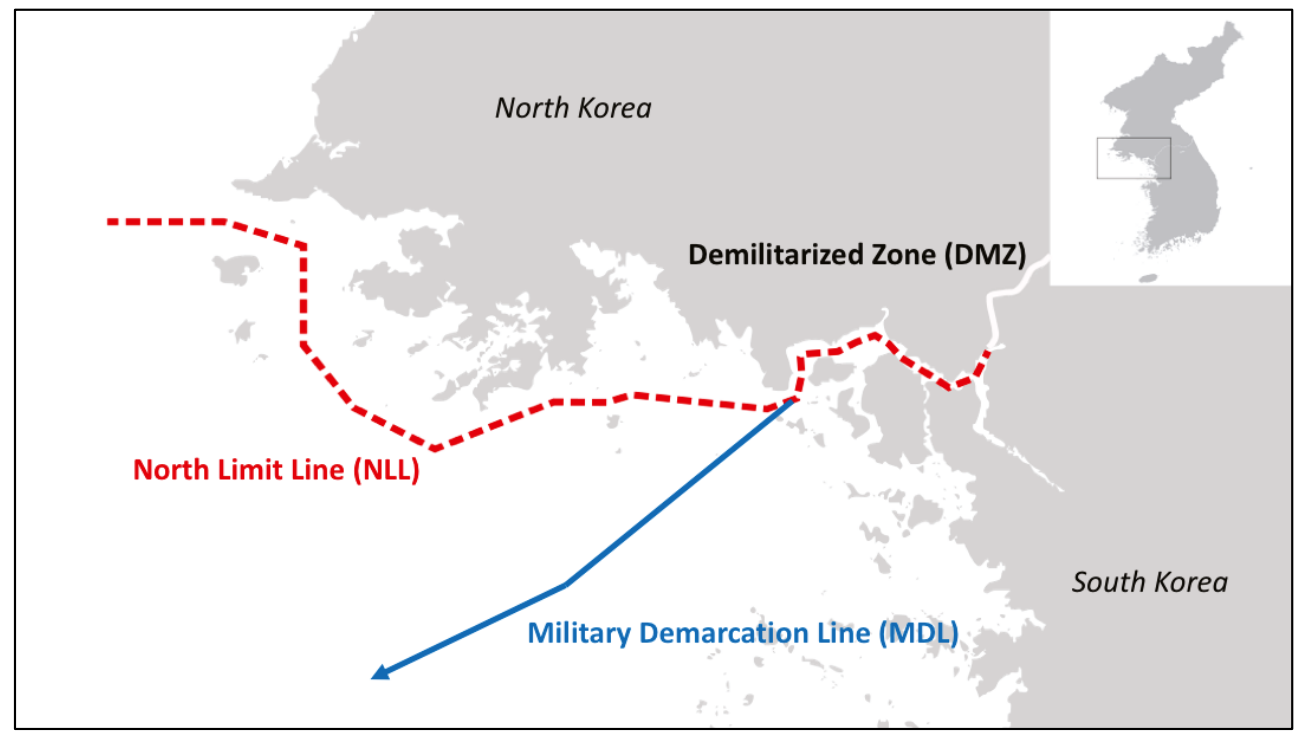

FIGURE 1 A Sketch Map of the Northern Limit Line and North Korea's Military Demarcation Line SOURCE: THIS SKETCH MAP IS PRODUCED BY THE AUTHORS BASED UPON A MAP FROM WIKIMEDIA COMMONS UNDER CREATIVE COMMONS LICENSE: MIDWAY, 'FILE:NORTHERN LIMIT LINE.SVG' (2009) < HTTPS://COMMONS.WIKIMEDIA.ORG/WIKI/ FILE:NORTHERN_LIMIT_LINE.SVG > ACCESSED 17 FEBRUARY 2021.

three-stage methodology is to construct a provisional equidistance line. Once this line has been drawn, an international judicial body then will proceed to determine whether any relevant circumstances require adjustment of the line as the second step. The third step is to examine whether the line results in any significant disproportion between the ratio of the respective coastal lengths and the ratio of the relevant areas allocated to each State. In some circumstances, the provisional equidistance line will become the final demarcation line. For instance, in Ghana / Côte d'Ivoire, the International Tribunal for the Law of the Sea (ITLOS) found that no relevant circumstance, in that case, would justify an adjustment of the provisional equidistance line. ${ }^{42}$ Therefore, the MDL claimed by North Korea, approximating an equidistance line between the coasts of North Korea and South Korea, is likely to be the starting point of the delimitation process and in some circumstances, might become the ultimate demarcation line.

42 Dispute Concerning Delimitation of the Maritime Boundary Between Ghana and Côte d'Ivoire in the Atlantic Ocean (Ghana / Côte d'voire) no 23, Judgment (September 2017) ITLOS Reports 2017, para 480. 
The jurisdiction ratione loci question can be examined from the perspectives of different stakeholders including foreign investors, North Korea, and judicial bodies. From the perspective of a foreign investor, the initiation of an investor-State dispute case is to obtain protection against discriminatory practices conducted by the host State. Therefore, it is natural for a foreign investor to support the jurisdiction ratione loci of the competent judicial body by claiming that the territorial scope stipulated by BITs signed by North Korea should cover the contested maritime areas claimed by North Korea.

From the perspective of a host State, North Korea might have mixed concerns. On the one hand, claiming that the territorial scope stipulated by its BIT s does not encompass the contested maritime areas can halt the exercise of jurisdiction by the competent judicial body, and, therefore, North Korea can be immune from any lawsuits pertaining to the contested Yellow Sea stemming from the BITs. On the other hand, this claim, however, might lead to negative implications for North Korea. The exclusion of the contested marine areas from the applicable territorial scope of the BITs might weaken North Korea's claims over the contested marine areas, as it might be interpreted that North Korea does not claim to 'exercise sovereign rights or jurisdiction in accordance with its national law and international law' over the contested marine areas. Another adverse effect is that the statements made by North Korea in an investor-State case might trigger the application of judicial estoppel. Judicial estoppel, as defined by Davis, 'prevents a party from asserting a position in one legal proceeding that directly contradicts a position taken by that same party in an earlier proceeding. ${ }^{43}$ The rationale behind the doctrine of judicial estoppel is to protect the integrity of the judicial bodies, not the litigants. In other words, this doctrine aims to prevent the litigants from manipulating the judicial bodies into making inconsistent decisions. ${ }^{44}$ Following this rationale, when it comes to positions of pure law, it does not matter whether the litigants change their positions in a subsequent case or not, as such a change does not threaten the judicial integrity. This is because, according to the principle of iura novit curia ('the court knows the law'), it is incumbent on the judges to find out the applicable law. However, in contrast, when it comes to positions of pure fact, the doctrine of judicial estoppel should, in general, apply.

Neither international jurisprudence nor statutory documents oblige adjudicators 'to actively investigate the facts in all circumstances', as the international

\footnotetext{
43 Kira A Davis, 'Judicial Estoppel and Inconsistent Positions of Law Applied to Fact and Pure Law' (2003) 89 Cornell L Rev 191, 192. 
judicial procedure is 'firmly based on the adversarial model in that the primary responsibility for gathering and presenting evidence lies with the parties, ${ }^{45}$ although in theory international judicial bodies are not restricted in their power of fact-finding or in their evidentiary competences to the facts provided by the parties. ${ }^{46}$ However, international judicial practice has shown that adjudicators tend to adopt a reactive attitude towards fact-finding. ${ }^{47}$ It is based on such a reality of international law that this research argues that in general, the litigants should not be allowed to contradict their positions of pure facts that are taken in an earlier proceeding. Otherwise, given that international judicial bodies are reactive in fact-finding, the litigants might easily manipulate the judicial bodies into making inconsistent decisions by changing the positions of pure facts in their favour. This conclusion echoes the holding of the Permanent Court of International Justice (PCIJ) in Legal Status of Eastern Greenland. In that case, M. Ihlen, the Norwegian Minister for Foreign Affairs, stated in the Ihlen declaration, to the Danish Minister on 22 July 1919 that 'I informed the Danish Minister that the Norwegian Government would not make any difficulties in the settlement of this question [i.e. Denmark's request to obtain the recognition of all the interested Powers of Denmark's sovereignty over the whole of Greenland]'48 The PCIJ concluded that the above undertaking involved in the Ihlen Declaration, which was apparently a fact rather than law, had an effect of estoppel, thereby making Norway 'under an obligation to refrain from contesting Danish sovereignty over Greenland as a whole, and a fortiori to refrain from occupying a part of Greenland'49

On the difference between law and fact, Judge Koroma's separate opinion in Costa Rica v Nicaragua sheds some light. In Judge Koroma's view, whether Costa Rica was entitled to sovereignty and territorial integrity under the UN Charter relied on the interpretation of relevant treaty provisions therein, and this question was a matter of law; in contrast, whether Costa Rica had the title to sovereignty over specific territory (i.e. the entirety of Isla Portillos)

45 Markus Benzing, 'Part Three Statute of the International Court of Justice: Procedure, Evidentiary Issues' in Andreas Zimmermann and others (eds), The Statute of the International Court of Justice: A Commentary (3rd edn, OUP 2019) 1375, para 12.

46 Xuechan Ma, 'Introducing Non-Legal Adjudicators as a Counterbalanced Measure for Non-Appearance in Inter-State Adjudication and Arbitration' (2017) 14 TDM 1, 2.

47 ibid 6.

48 Legal Status of Eastern Greenland (Denmarkv Norway) (Judgement) [1933] PCIJ, para 190.

49 ibid para 202. 
was related to the plausibility of factual claims. ${ }^{50}$ Therefore, arguably, whether North Korea exercises sovereign rights or jurisdiction in accordance with its national law and international law over the contested marine areas is primarily a question of fact, as this question must be answered by references to facts and evidence, which relates to the status and extent of the exercise of sovereign rights or jurisdiction by North Korea in the areas concerned, as well as inferences arising from those facts. To this effect, if North Korea makes a statement in an investor-State case that the contested marine areas do not belong to the territorial scope of the BITs, this statement might be used to be against North Korea in a subsequent case, for example, a maritime dispute case involving North Korea and South Korea. Therefore, in its best interest, chances are slight that North Korea would pose objections to the jurisdiction ratione loci of the competent judicial body.

A further question is whether the competent judicial body could motu proprio trial the issue of jurisdiction ratione loci even when the parties do not challenge this issue. According to the principle of nemo judex sine actore (no action, no judge), the answer seems to be in the negative. However, according to the principle of 'competence of competence', a judicial body is empowered to rule on its jurisdiction. International jurisprudence also indicates that a judicial body must satisfy itself that it has jurisdiction to address the case as submitted even if no disagreement exists between the parties on the jurisdiction. For instance, in Ghana/Côte d'voire, both parties agreed on the jurisdiction of the Special Chamber of the ITLOS in that case, and yet, the Special Chamber still felt it necessary to check whether it had jurisdiction regarding the submission..$^{51}$

Yet, what is the chance of an international judicial body holding that a contested marine area falls within the applicable territorial scope of a BIT? The two investor-State arbitrations, namely PJSC Ukrnafta $v$ Russia and Stabil LLC and ten others $v$ Russia, are of significant relevance to the discussion here. On 3 June 2015, these two arbitral proceedings were commenced based on the Agreement between the Government of the Russian Federation and the Cabinet of Ministers of Ukraine on the Encouragement and Mutual Protection of Investments dated 27 November 1998 (Ukraine-Russia BIT) under the United Nations Commission on International Trade Law (UNCITRAL)

\footnotetext{
$5^{\circ}$ Certain Activities Carried Out by Nicaragua in the Border Area (Costa Rica v Nicaragua) (Separate Opinion of Judge Koroma) [2011] ICJ Rep, para 11. 
Arbitration Rules $1976 .{ }^{52}$ The claimants alleged that Russia had breached its obligations under the Ukraine-Russia BIT by interfering with and ultimately expropriating their investments in petrol stations located in Crimea since its annexation by Russia in $2014 .{ }^{53}$ It is important to note that whether the annexation of Crimea by Russia is lawful under international law remains disputable. For example, Dumberry has argued that Crimea should remain with Ukraine under international law, as the annexation violated the rule of the prohibition of the use of force. ${ }^{54}$ To this extent, Crimea should be considered as a territory in dispute. Despite Russia's non-appearance, the two arbitral tribunals, composed of the same members, issued unanimous awards on jurisdiction. ${ }^{55}$ Though neither the awards on jurisdiction nor final awards were made available to the public, it was reported that in a public hearing in October 2018, the Tribunal confirmed the upholding of the jurisdiction in both cases and decided that by annexing Crimea, Russia had assumed responsibility under the Ukraine-Russia BIT to protect existing Ukrainian investments in Crimea. ${ }^{56}$ By the same token, international judicial bodies are likely to deem the contested marine areas in the Yellow Sea claimed by North Korea to be part of the 'the territorial land, territorial waters, exclusive economic maritime zone and continental shelf over which it exercises sovereign rights or jurisdiction in accordance with its national law and international law' as stipulated in the existing BITs signed by North Korea.

Increasing demands for hydrocarbon resources owing to economic development in the future might turn the rich potential of oil and gas in the contested marine areas of the Yellow Sea into an excellent foreign investment opportunity. To secure potential investments in these areas, this research suggests that the future BITs adopt a similar 'territorial scope' clause contained in the existing BITs but add a specific reference to include marine areas claimed by North Korea. The 'territorial scope' clause can thus be framed as follows:

$52 \quad$ PCA, Press Release (2 May 2016) <https://pcacases.com/web/sendAttach/1703> accessed 17 February 2021.

53 PCA, Press Release (4 July 2017) <https://pcacases.com/web/sendAttach/2186> accessed 17 February 2021.

54 Patrick Dumberry, 'Requiem for Crimea: Why Tribunals Should Have Declined Jurisdiction over the Claims of Ukrainian Investors Against Russian Under the Ukraine-Russia BIT' (2018) 9 JIDS 506, 506.

$55 \quad$ PCA (n 53$)$.

56 Kateryna Honcharenko, 'Case Note: PJSC Ukrnafta v the Russian Federation (UNCITRAL, PCA Case No 2015-34) and Stabil, LLC and Others $v$ the Russian Federation (UNCITRAL, PCA Case No 2015-35)' (2019) (3) The Resolver: The Quarterly Magazine of the Chartered Institute of Arbitrators 16, 16. 
North Korea's territory over which a BIT shall apply include the territorial land, territorial sea, exclusive economic zone and continental shelf over which it exercises or claims to exercise sovereign rights or jurisdiction in accordance with its national law and international law. ${ }^{57}$

\subsection{Substantive Protection}

The studied BITs all contain provisions on substantive protection to foreign investors and their investment. These provisions usually consist of full protection and security (FPS), fair and equitable treatment (FET), the umbrella clause, ${ }^{58}$ national treatment (NT) and most-favoured-nation (MFN) treatment for foreign investment. A systemic and comparative study of these provisions in existing North Korean BITs in this section seeks to provide good practices and lessons learned that could inform the formulation of future North Korean BITs.

\subsubsection{Full Protection and Security, and Fair and Equitable Treatment}

A majority of studied BIT s contain FPS and FET in two separate provisions, while some contain FPS and FET in one single provision. ${ }^{59}$ Some BIT s mention FET twice: the first absorbed in the FPS provision, and the second referred to again in the investment treatment provision. ${ }^{60}$ Which formulation would maximize the protection of investment?

To answer this question, a close examination of existing North Korean BITs might help. It is noted that most North Korean BITs grant FPS at all times (i.e. from entry to exit) for foreign investment. ${ }^{61}$ FPS guarantees that contracting States have an obligation to provide protection against forcible interference by individuals and State organs such as armed forces. ${ }^{62}$ Some arbitral tribunals expanded this concept to further request States to provide legal safeguards

57 Singapore-North Korea BIT (n 26) art 1.4.

58 North Korea's BIT s with Bangladesh, China, Denmark, Switzerland, Syrian Arab Republic, and Thailand include umbrella clauses.

59 For instance, the BITs with Switzerland, Syrian, and Thailand.

6o For instance, the BITs with Czech Republic, Egypt, Malaysia, and Slovakia mentioned FET twice in the treaty provisions.

61 The following BITs expressly include a 'full protection and security' clause in the treaty provisions: the North Korean BITs with China, Czech Republic, Denmark, Egypt, Malaysia, Mongolia, Slovakia, Switzerland, Syrian Arab Republic, and Thailand. ChinaNorth Korea BIT art 2.2 uses the word 'constant protection' instead of 'full protection'. However, in this situation, arbitral practice shows that the wording of the treaty is not decisive to determine the scope of full protection and security. Christoph Schreuer, 'Full Protection and Security' (2010) 1 JIDS 1, 16. 
for foreign investment. ${ }^{63}$ It means that host States are obliged to provide a secure environment and stable judicial system to foreign investment and offer an available remedy to investors. For instance, in the CMEv Czech Republic case, the Tribunal held that Czech Republic as the host State had an obligation not to withdraw or devalue foreign investment by neither amendment of its laws nor actions of its administrative bodies. ${ }^{64}$ However, the scope of the legal safeguards is not unlimited. States have a due diligence obligation to promote foreign investment and indeed enjoy a rather wide discretion to discharge it for giving priority to its own economic development or considering resource restraints. ${ }^{65}$ Turning to FET provisions, they are prescribed in all the studied BITs. FET requests contracting States to provide a stable, transparent legal protection to investors' activities in accordance with the principle of due process and good faith. ${ }^{66}$ The primary goal of FET is to meet investors' expectation concerning legal consistency, stability, and predictability of the host States, which can, in turn, attract more foreign investment. ${ }^{67}$

International jurisprudence often considers FPS and FET interrelated. ${ }^{68}$ For instance, the Occidental Exploration and Production Company $v$ Ecuador Tribunal held that 'a treatment that is not fair and equitable automatically entails an absence of full protection and security of the investment'.69 In the Wena v Egypt case, the Tribunal concluded that FET was violated when the

\footnotetext{
63 ibid 17.

64 CME Czech Republic BVv The Czech Republic, Partial Award (13 September 2001) para 613.

65 Cordero Moss Giuditta, 'Full Protection and Security' in August Reinisch (ed), Standards of Investment Law (OUP 2008) 131, 136. Schreuer (n 62) 14.

66 Rudolf Dolzer and Christoph Schreuer, Principles of International Investment Law (2nd edn, OUP 2012) 145-61.

$67 \quad$ ibid 161.

68 Schreuer (n 62) 13. For instance, Wena Hotels Limited v Arab Republic of Egypt, Case No ARB/98/04, Award (8 December 2000) paras 84-95. The treaty applied in this case is the United Kingdom and the Arab Republic of Egypt Agreement for the Promotion and Protection of Investments, art 2(1) of which guaranteed that '[i]nvestments of nationals or companies of either Contracting Party shall at all times be accorded fair and equitable treatment and shall enjoy full protection and security in the territory of the other Contracting Party'.

69 Occidental Exploration and Production Company $v$ The Republic of Ecuador, LCIA Case No UN3467, Final Award (1 July 2004) para 187. In this case, the treaty applied is the Ecuador-US BIT, art II (3)(a) of which states: 'Investment shall at all times be accorded fair and equitable treatment, shall enjoy full protection and security and shall in no case be accorded treatment less than that required by international law.' See also Azurix Corp $v$ The Argentine Republic, ICSID Case No ARB/o1/12, Award (14 July 2006) para 406.
} 
State failed to provide FPS, including the failure of preventing the seizure of the investment and of taking restoring measures. ${ }^{70}$

However, the focuses of FPS and FET are indeed different. FPS asks States to take proactive measures including establishing a factual legal framework to ensure security and taking necessary measures to protect investments against adverse actions. ${ }^{71}$ In contrast, FET requests States to desist or refrain from unfair and inequitable treatment for foreign investment. ${ }^{72}$ Therefore, despite the interrelationship between FPS and FET, this article would encourage BIT s to contain both clauses to maximise the possible legal protection of foreign investment.

\subsubsection{The Umbrella Clause}

Concerning the studied BITs, six of them include the umbrella clause. ${ }^{73}$ The umbrella clause, also known as the obligations observance clause, requests host States to observe obligations that they have entered into with regard to foreign investment, reinforcing the fundamental principle of pacta sunt servanda in public international law. ${ }^{74}$ For instance, Article 2.3 of the North Korea-Denmark BIT provides: 'Each Contracting Party shall observe any obligation it may have entered into with regard to investments of investors of the other Contracting Party.' A literal reading of this clause seems to suggest that investors can initiate international arbitration when a host State (including its organs and local governments) breaches an investment contract, because this breach also constitutes a breach of the BIT. ${ }^{75}$ However, is this formulation of the umbrella clause the best strategy for North Korean BIT s?

In real cases, the implications of an umbrella clause are not this straightforward but instead quite controversial, ${ }^{76}$ as evidenced in distinctive decisions that arbitral tribunals made in the Société Générale de Surveillance $S A$ (SGS)

\footnotetext{
$70 \quad$ Wenav Egypt (n 68) paras 84-95.

71 Schreuer (n 62) 14.

72 ibid.

73 The North Korean BITs with China, Denmark, Switzerland, Syrian and Thailand.

74 Stephan W Schill, 'Enbaling Private Ordering: Function, Scope and Effect of Umbrella Clauses in International Investment Treaties' (2009) 18 Minn J Intl L 1, 2.

75 Dolzer and Schreuer (n 66) 169.

76 Antony C Sinclair, 'The Origins of the Umbrella Clause in the International Law of Investment Protection' (2004) 20 Arb Intl 411, 411. Shotaro Hamamoto, 'Parties to "Obligations" in the Obligations Observance ("Umbrella") Clause' (2015) 30 ICSID Rev-FILJ 449, 449.
} 
$v$ Pakistan and $S G S v$ Philippines. ${ }^{77}$ In the $S G S v$ Pakistan case, the umbrella clause under discussion is contained in Article 11 of the Pakistan-Switzerland BIT under the title 'Observance of Commitments' ('Either Contracting Party shall constantly guarantee the observance of the commitments it has entered into with respect to the investments of the investors of the other Contracting Party.'). ${ }^{78}$ The Tribunal did recognise the possibility of converting a violation of an investor-State contract into a violation of a BIT so far as clear and persuasive evidence indicated such an intention in the BIT. ${ }^{79}$ However, in the circumstances of this case, the Tribunal noted that the umbrella clause was placed separately from the substantive provisions (i.e. Articles 3 to 7 of the BIT) and considered that such a treaty structure reflected that Article 11 'was not meant to project a substantive obligation' ${ }^{80}$ Therefore, the Tribunal concluded that the 'Observance of Commitments' provision, in this case, did not intend to transform a contractual breach into a BIT breach. ${ }^{81}$ In the subsequent $S G S v$ Philippines case, Article $\mathrm{X}(2)$ of the Philippines-Switzerland BIT includes an umbrella clause with a broad reach ('Each Contracting Party shall observe any obligation it has assumed with regard to specific investments in its territory by investors of the other Contracting Party.'). ${ }^{82}$ The Tribunal held that Article $\mathrm{X}(2)$ provided 'assurances to foreign investors with regard to the performance of obligations assumed by the host State under its own law with regard to specific investments ... to help secure the rule of law in relation to investment protection' ${ }^{83}$ In other words, a host State would breach the BIT if it fails to perform binding (including contractual) commitments, which it has assumed with regard to specific investments. ${ }^{84}$

77 SGS Société Générale de Surveillance SA v Islamic Republic of Pakistan, ICSID Case No $\mathrm{ARB} / \mathrm{or} / 13$, Decision on Jurisdiction (6 August 2003). In this case, SGS signed a preshipment inspection agreement with Pakistan. SGS Société Générale de Surveillance $S A v$ Republic of the Philippines, ICSID Case No ARB/o2/6, Decision of the Tribunal on Objections to Jurisdiction (29 January 2004). The SGS signed an agreement concerning the import supervision services with Philippines.

${ }_{78} S G S v$ Pakistan (n 79) paras 163-74. Art 11 of the Pakistan-Switzerland BIT states '[E]ither Contracting Party shall constantly guarantee the observance of the commitments it has entered into with respect to the investments of the investors of the other Contracting Party'.

79 ibid para 172.

8 o ibid para 170 .

81 ibid paras $163-73$.

$82 \quad S G S v$ Philippines $(\mathrm{n} 77)$ para 115.

83 ibid para 126.

84 ibid para 128 . 
The umbrella clauses in some existing North Korean BITs (e.g. the North Korea-Denmark BIT) are phrased in broad terms and share more similarity with the one contained in the Philippines-Switzerland BIT, and therefore, the holding in $S G S v$ Philippines likely applies. This is also confirmed by international jurisprudence developed after $S G S v$ Pakistan and $S G S v$ Philippines. ${ }^{85}$ It is further noted that the umbrella clause is not limited to contractual commitments. ${ }^{86}$ In Enron $v$ Argentina case, the Tribunal concluded that the phrase 'any obligation' in the umbrella clause in the Argentina-US BIT should be interpreted to cover all obligations, regardless of their nature, ${ }^{87}$ including a State's obligations assumed under unilateral acts through legislation and regulation. ${ }^{88}$ It follows that the enactment of law and regulations, which causes the losses of investment, may entail the violation of States' obligations under the umbrella clause in a BIT. ${ }^{89}$ Therefore, this research recommends the future BIT s with North Korea to phrase the umbrella clause in broad terms (e.g. 'any obligations') to ensure substantive protection. As inspired by $S G S v$ Pakistan, an additional recommendation is to place the umbrella clause together with the substantive provisions, to indicate that this clause provides substantive standards to be followed by States.

\subsubsection{National Treatment and Most-Favoured-Nation Treatment}

Almost all the studied BITs contain both NT and MFN clauses in either one article or two separate articles. ${ }^{90}$ This shows that North Korea is open to adopting these two standards into its BITs. NT requests host States to make no negative distinction between foreign and their national investors and shall take positive measures to raise the level of promotion and protection of foreign

85 Katia Yannaca-Small, 'Interpretation of the Umbrella Clause in Investment Agreements' (2006) OECD Working Paper 2006/o3, 22.

86 María Cristina Gritón Salias, 'Do Umbrella Clauses Apply to Unilateral Undertakings?' in Christina Binder and others (eds), International Investment Law for the 21st Century: Essays in Honour of Christoph Schreuer (OUP 2009) 490, 496.

87 Enron Corporation and Ponderosa Assets, LP v Argentine Republic (also known as Enron Creditors Recovery Corp and Ponderosa Assets, LP v The Argentine Republic) ICSID Case No ARB/o1/3, Award (22 May 2007) para 274. The applicable treaty in this case is the Argentina-US BIT art II $(2)(\mathrm{c})$, which states: '[E] ach Party shall observe any obligation it may have entered into with regard to investments'.

88 Gritón Salias (n 88) 496. See also Enron v Argentina (n 87) paras 274-77; SGS v Pakistan (n 77$)$ para 166.

$89 \quad$ Gritón Salias (n 86) 495-96.

9o Two exceptions are the North Korean BITs with Malaysia and Switzerland, which do not prescribe NT. 
investors to that of domestic nationals. ${ }^{91}$ MFN requests a host State to treat investors from another State in a manner at least as favourable as investors from a third State. ${ }^{92}$ However, can any improvement be made based upon the NT and MFN clauses in existing BIT s?

A potential point of discussion in negotiating a future BIT with North Korea is whether NT and MFN apply at pre- and/or post- establishment of investment. Pre-establishment treatment covers the entry conditions of the investment. ${ }^{93}$ Post-establishment treatment applies from the start-up to the liquidation and disposition of the investment. ${ }^{94}$ Applying MFN to the preestablishment phase means that a host State cannot grant access to certain sectors to some investors while not to other investors or to impose additional conditions, or in other words, foreign investors should be granted the rights to invest on the same terms as other foreign counterparts. ${ }^{95}$ In contrast, limiting the application of MFN to the post-establishment phase entails that MFN only protects investors after their entry to the market, but before that host States can set different entry requirements for foreign investors. ${ }^{96}$ The same discussion applies to NT.

According to international law as it currently stands, the general principle is that host States maintain the power to screen and regulate the entry of foreign investment to the domestic market in line with their industrial policies and development needs. ${ }^{97}$ In practice, the pre-establishment phase of investment is often left to be determined by domestic laws and policy, which is easier to be adjusted than in the case of a BIT, ${ }^{98}$ and MFN and NT generally apply to the post-establishment phase. ${ }^{99}$ However, one exception is that MFN and

$91 \quad$ ibid 199.

92 ibid 207.

93 UNCTAD, 'Most-Favoured-Nation Treatment' (2010) UNCTAD Series on Issues in International Investment Agreements II 19; OECD, 'Negotiating Group on the Multilateral Agreement on Investment, Treatment of Investors and Investments' (11 October 1995) DAFFE/MAI (95) 3 .

94 ibid 20.

95 Suzy H Nikièma, 'The Most-Favoured-Nation Clause in Investment Treaties' (February 2017) IISD Best Practice Series 9.

$96 \quad$ ibid 7 .

97 WTO, 'Modalities for Pre-establishment Commitments Based on a GATS-Type, Positive List Approach' (19 June 2002) WT/WGTI/W/120 (02-3397).

98 Nikièma (n 95).

99 UNCTAD, 'Mapping of the IIA Content' <https://investmentpolicy.unctad.org/ international-investment-agreements $>$ accessed 17 February 2021. 2338 out of 2576 mapped treaties contain MFN in the post-establishment phrase, 194 out of 2576 contain MFN in the pre and post-establishment phrase, and no treaty contains MFN 
NT can apply to the pre-establishment phase of investment if a BIT explicitly provides so. A notable example is the North American Free Trade Agreement (NAFTA), ${ }^{100}$ which expressly mentions that MFN and NT apply to the establishment, acquisition, expansion of investment.

In terms of the existing North Korean BITs, none of them have explicitly mentioned the application of MFN and NT to the pre-establishment phase of investment, and therefore, MFN and NT in these BITs should be interpreted as applicable to the post-establishment phase of investment only. Depending on specific needs, a State might consider including the question about whether MFN and NT cover the pre-establishment phase of investment (as the NAFTA does) as a potential point of discussion during its BIT negotiation with North Korea.

Another point of discussion relates to the applicability of MFN and NT in SEZs, where North Korea grants more beneficial investment conditions (e.g. fiscal and regulatory incentives, and infrastructure support) than non-SEZs. All the existing North Korean BITs exclude the application of MFN and NT to SEZs. For instance, Article 3.4 of the North Korea-China BIT sets forth that MFN and NT presented in prior sections:

shall not be construed so as to oblige one Contracting Party to extend to the investors of the other Contracting Party the benefit of any treatment, preference of privilege by virtue of: (a) any customs union, free trade zone, economic union and any international agreement resulting in such customs union, free trade zone and economic union ... ${ }^{101}$

The non-application of MFN and NT in domestic SEZs is more relevant to the discussion here, as North Korea has not joined any regional or international

in the pre-establishment phrase. 2020 out of 2576 mapped treaties contain NT in the post-establishment phrase, 168 out of 2576 treaties contain NT in the pre- and postestablishment phrase, and no treaty contains NT in the pre-establishment phrase only.

100 North American Free Trade Agreement (signed on 17 December 1992, came into force on 1 January 1994) (NAFTA). Art 1103 of NAFTA: 'Each Party shall accord to investors of another Party treatment no less favourable than that it accords, in like circumstances, to investors of any other Party or of a non-Party with respect to the establishment, acquisition, expansion, management, conduct, operation, and sale or other disposition of investments'.

101 China-North Korea BIT art 3.4. The same and similar provisions also can be found in the rest of studied BITs. 
'customs union, free trade zone and economic union'.102 Since the Rason SEZ was established in 1991, North Korea has set up 9 central-level SEZs and 14 provincial-level SEZs by late $2015 .{ }^{103} \mathrm{SEZ}$ s can have different names such as economic development zones, free zones, export processing zones, and industrial parks. ${ }^{104}$ When negotiating a BIT with North Korea, the applicability of MFN and NT to North Korean SEZs is a very important matter for a country to take into account because presently, SEZs remain a fundamental approach for North Korea to deal with foreign investment. ${ }^{105}$

\subsection{Expropriation and Compensation}

The fact that the Korean War has not formally ended owing to the absence of a peace treaty might have certain legal implications for foreign investors, where the expropriation and compensation clause performs an important role. All the studied BIT s include provisions relating to expropriation against and compensation for the investment of investors from the contracting parties.

First, the provisions on expropriation use largely identical language, which provides that any measures of expropriation, nationalisation or other measures of effect equivalent to nationalisation or expropriation (generally called 'expropriation') shall not be taken unless the following four cumulative conditions are satisfied: (1) for the public interests; (2) under the domestic legal procedure; (3) without discrimination; and (4) against compensation. Most of the BITs also provides the investor with a right to prompt review. ${ }^{106}$ It means that the investor affected is entitled to request a judicial or other independent authority of the contracting party to review whether the measure of

102 By far, no available database shows that North Korea joined any customs unions or economic unions. According to the UNCTAD database, North Korea also did not sign any international agreement resulting in a customs union, free trade zone and economic union. UNCTAD, 'Democratic People's Republic of Korea' <https:// investmentpolicy.unctad.org/international-investment-agreements/countries/11o/koreademocratic-people-s-republic-of $>$ accessed 17 February 2021.

103 Ministry of Commerce of the People's Republic of China (n 17) 46-47.

104 UNCTAD, 'World Investment Report 2019' (2019) 133.

105 Art 37 of the 1998 Constitution Law of North Korea. The 1998 Constitution specifically encouraged North Korean institutions, enterprises or associations to undertake foreign investment businesses with corporations and individuals from foreign countries in special economic zones.

106 Foreign Investment Law of North Korea art 19 contains the similar provision, which stipulates that: "The States shall not nationalize or expropriate the properties of foreigninvestors, foreign-invested enterprises and banks. Should expropriation be required for public interests, notification thereof shall be made in advance and sufficient compensation for its value shall be made through legal procedures.' 
expropriation or valuation is taken in the manner compatible with its domestic laws. ${ }^{107}$

Second, the provisions on compensation for losses or damage can be roughly divided into two types. The first type simply sets forth that in case the investment of the investor of one contracting party suffer losses or damage due to war or other armed conflicts, a state of national emergency, revolt, insurrection or riot in the territory of the other contracting party, the latter contracting party is obliged to accord treatment, which may include restitution, indemnification, compensation or other settlement, if any, no less favourable than that it accords to investors of any third State or its own investors. It infers that the contracting party can accord no treatment provided that it does not grant any treatment to any third State or its own investors. Apart from the requirement of the no-less-favourable treatment, the second type of provisions on compensation provides that under certain circumstances, the contracting party cannot be exempt from paying compensation. Specifically speaking, the contracting party is obliged to accord restitution or prompt adequate and effective compensation. This is to the extent that the losses or damage suffered by the investor in the territory of that contracting party result from requisitioning or destruction by its forces or authorities, which is neither caused in combat action nor required by the necessity of the situation.

Notably, the Korean Armistice Agreement was signed on 27 July 1953 by US Army Lieutenant General William Harrison, Jr., representing the UNC, North Korean General Nam II representing the Korean People's Army (KPA), and the Chinese People's Volunteer Army (PVA). An armistice does not put an end to the war but merely suspends military operations between the belligerent parties. Article 36 of Hague Regulations Respecting the Laws and Customs of War on Land stipulates that:

An armistice suspends military operations by mutual agreement between the belligerent parties. If its duration is not defined, the belligerent parties may resume operations at any time, provided always that the enemy is warned within the time agreed upon, in accordance with the terms of the armistice. ${ }^{108}$

\footnotetext{
107 The BIT s prescribing a right to prompt review include those signed with North Korea with Czech Republic, Denmark, Egypt, Mongolia, Syrian, Singapore, Slovakia, and Thailand.

108 The Hague Regulations Respecting the Laws and Customs of War on Land (18 October 1907) art 36.
} 
As mentioned earlier, on 27 April 2018, North Korea and South Korea signed the Panmunjom Declaration, in which both sides agreed to work together to end the Korean War and start a new era of peace. However, the Panmunjom Declaration contains mere non-binding political declarations and does not amount to a peace treaty that can bring an official end to the Korean War. ${ }^{109}$ Therefore, technically speaking, the Korean War is still ongoing. What are the legal implications of this conclusion for foreign investors? For example, if the investments of foreign investors suffer losses or damage within the territories of North Korea, can North Korea use war as a justification to exempt itself from paying compensation to these investors to the extent that it does not grant any treatment to any third State or its own investors?

In theory, this risk exists, as the Korean War has not been formally ended. It is also noted that North Korea is not a party to the Multilateral Investment Guarantee Agency (MIGA), which is an international financial institution that offers political risk insurance and credit enhancement guarantee to investments against non-commercial risks including wars, terrorism and civil disturbance. Given that MIGA insures foreign investment 'originating in any MIGA member country that ... [is] destined for any developing member country,'110 foreign investment in the territory of a non-member State such as North Korea is not eligible to obtain the protection from the MIGA regime. Before a peace treaty comes into existence and takes effect, for risk prevention, other States may, in their BIT s with North Korea, ask North Korea to guarantee that it will not use the Korean war as an excuse to evade its obligations of paying compensation.

\subsection{Dispute Settlement}

All the studied North Korean BITs offer foreign investors an access to pursue remedies against host States for violation of their rights. These BIT s consist of two types of dispute settlement clauses: the State-to-State dispute settlement (SSDS) clause, and the investor-State dispute settlement (ISDS) clause. The rights to claim are also granted by North Korean domestic law, which confirm the application of both local and international remedies. For instance, the Foreign Investment Law provides that any foreign investment dispute

109 Angela Semee Kim, 'An End to the Korean War: The Legal Character of the 2018 Summit Declarations and Implications of an Official Korean Peace Treaty' (2019) 9 Asian J Intl L 206, 211.

110 Eun Kwan Choi, E Han Kim and Yesook Merrill, North Korea in the World Economy (Routledge 2003) 51. 
should be settled through negotiation, and in case of failure in negotiation, it shall be settled by a court or an arbitration body in North Korea, or to be brought to an arbitration agency in a third country. ${ }^{111}$ The 2012 Rason SEZ Law further specifies that foreign investors can file administrative litigation, administrative mediation, or arbitration with arbitral institutions including those established inside the SEZ or outside North Korea to resolve investment disputes. ${ }^{112}$

\subsubsection{State-to-State Dispute Settlement Mechanism}

The SSDS clause under North Korean BIT s usually concern disputes relating to the interpretation and application of BIT s. ${ }^{113}$ All the studied North Korean BIT s, except the one with Bangladesh, provide a general two-step procedure for the settlement of inter-State disputes (see Table 3). ${ }^{114}$

The first step sets up a cooling-off period for the disputant parties to conduct consultations and negotiations between them with regard to the dispute at stake. Consultations and negotiations are part of the peaceful means to settle international disputes. ${ }^{115}$ Consultation, which is one kind of negotiation in the broad sense, requests a party to consult with the affected party before the former makes a decision or takes a proposed action that may harm the latter. ${ }^{116}$ Respecting the cooling-off period, ${ }^{117}$ most of the studied BITs allow a State party to make an arbitration request if a dispute cannot be settled

111 The Law of The Democratic People's Republic of Korea on Foreign Investment (adopted by Resolution No 17 of the Standing Committee of the Supreme People's Assembly on 5 October 1992, and amended by Decree No 484 of the Presidium of the Supreme People's Assembly on 26 February 1999).

112 Ministry of Commerce of the People's Republic of China (n 17) 48-49.

113 North Korean BITs with Bangladesh, China, Czech Republic, Egypt, Macedonia, Malaysia, Singapore, Slovakia, Switzerland, Syrian, and Thailand. Take one of the earliest North Korea signed BIT as an example. Art 9(1) of the Egypt-North Korea BIT states that, '[d]isputes between the Contracting Parties concerning the interpretation or application of the agreement shall - if possible - be settled through negotiations between the governments of the Contracting Parties.' However, the SSDS in art 8(1) of the Mongolia-North Korea BIT applies to '[a]ny disputes that may arise between the Contracting Parties concerning this agreement'.

114 North Korean BIT s with China, Czech Republic, Denmark, Egypt, Macedonia, Malaysia, Mongolia, Singapore, Slovakia, Switzerland, Syria, and Thailand. The Bangladesh BIT only requires that the contracting State has an obligation to enter consultations from the contracting party with necessary arrangements for holding these consultations without delay.

115 Declaration on Principles of International Law Concerning Friendly Relations and Co-operation Among States in Accordance with the Charter of the United Nations, UNGA Res 25/2625 (XXV) (24 October 1970) A/RES/25/2625.

116 J G Merrills, International Dispute Settlement (CUP 2017) 2-3.

117 UNCTAD, 'Dispute Settlement: State-State' (2003) 14-15. 
through consultations and negotiations within certain periods, usually three to six months. ${ }^{118}$

However, contracting States should be aware that in practice the cooling-off period might be treated as 'a mere defect of form' that would not hamper the jurisdiction if courts or tribunals find that the dispute in question apparently cannot be settled through consultations and negotiations within the coolingoff period. For instance, in Nicaragua, the Treaty of Friendship, Commerce and Navigation between the United States and Nicaragua, which provided the jurisdictional basis for this case, stipulated as follows:

Any dispute between the Parties as to the interpretation or application of the present Treaty, not satisfactorily adjusted by diplomacy, shall be submitted to the International Court of Justice, unless the Parties agree to settlement by some other pacific means. ${ }^{119}$

The United States claimed that the reference in the above provision to disputes 'not satisfactorily adjusted by diplomacy' required an attempt to adjust the dispute as a prerequisite of a submission to the ICJ. ${ }^{120}$ In the circumstances of this case, the United States further argued that the fact that Nicaragua had never raised in negotiations with it the application or interpretation of the treaty in question amounted to a failure to satisfy the treaty's own terms for invoking the compromissory clause. ${ }^{121}$ However, the ICJ did not support the United States' argument, holding that the prior negotiation amounting to no more than 'a mere defect of form' would not be insisted upon as a prerequisite for jurisdiction if the disputes apparently could not be adjusted by diplomacy.122

In the second step, an arbitral tribunal consisting of three arbitrators shall be constituted. Depending on the specific treaties, within either two or three months of the receipt of the request for arbitration, each contracting State shall appoint one member of the tribunals. Afterwards, these two members then select the chairman of the tribunal. The chairman usually shall be appointed within two to three months from the date of the appointment of the other two members. North Korean BITs usually require that the chairman shall be

\footnotetext{
118 Christoph Schreuer, 'Travelling the BIT Route of Waiting Periods, Umbrella Clauses, and Forks in the Road' (2004) 5JWIT 231, 233. The Singapore-North Korea BIT does not input a specific negotiation period.

119 Military and Paramilitary Activities in and Against Nicaragua (Nicaragua v United States of America) (Judgment of Jurisdiction and Admissibility) [1984] ICJ Rep 70, para 81.

120 ibid.

121 ibid.

122 ibid para 83.
} 
TABLE 3 SSDS Clauses in the Studied BITs

\begin{tabular}{|c|c|}
\hline & Summary \\
\hline $\begin{array}{l}\text { Step } 1 \\
\text { Consultation and/ } \\
\text { or Negotiation } \\
\text { Between Parties }\end{array}$ & $\begin{array}{l}\text { Through diplomatic channel: China, Macedonia, Malaysia, } \\
\text { Mongolia, Switzerland }\end{array}$ \\
\hline \multirow[t]{3}{*}{ Cooling-Off Period } & No specific period required: Singapore, Malaysia \\
\hline & 3 months (from the beginning of the dispute): Denmark \\
\hline & $\begin{array}{l}6 \text { months (from the beginning of the dispute): China, Czech } \\
\text { Republic, Egypt, Macedonia, Slovakia, Switzerland, Syrian, } \\
\text { and Thailand }\end{array}$ \\
\hline $\begin{array}{l}\text { Step } 2 \\
\text { Submission to an } \\
\text { Ad Hoc Tribunal }\end{array}$ & $\begin{array}{l}\text { 1. Three arbitrators. } \\
\text { 2. Each State appoints one member of the Tribunal, and } \\
\text { these two members nominate the chairman. } \\
\text { 3. Particular requirement of the nationality of the } \\
\text { chairman: } \\
\text { The State of the chairman shall maintain diplomatic } \\
\text { relations with both disputing States: China, Macedonia, } \\
\text { Singapore, Syrian, and Thailand. } \\
\text { 4. Failure to constitute the arbitral tribunal: } \\
\text { A request to the International Court of Justice to appoint } \\
\text { the chairman: China, Czech Republic, Denmark, Egypt, } \\
\text { Macedonia, Malaysia, Mongolia, Singapore, Slovak } \\
\text { Republic, Switzerland, Syrian, Thailand. }\end{array}$ \\
\hline
\end{tabular}

SOURCE: AUTHOR COMPILATION BASED ON STUDIED BITS

a national of a third country. ${ }^{123}$ The arbitral tribunal shall reach the award by a majority of votes, which is binding upon the dispute parties. About the costs of the proceeding, the parties in dispute shall bear their respective costs, including the costs of its appointed arbitrators, the costs of its representation in the

123 When contracting States fail to constitute the arbitral tribunals after the required negotiation period, the contracting State may make a request to the president of the ICJ to appoint the chairman of the arbitral tribunal. When the president happens to be a national of either contracting party, or if the president is prevented from the discharge of this functions, the member of the ICJ next in seniority, including the vice-president, will then be invited to make the appointments. But it reminds that the ICJ is not responsible for the substantive disputes, but only for the selection of the arbitrator in accordance with the BIT. 
arbitral proceedings, the relevant costs of the chairman and other remaining expenses in equal.

\subsubsection{Investor-State Dispute Settlement Mechanism}

ISDS provisions in BITs provide foreign investors with direct access to bring claims against host States if their investment is expropriated or they suffer from unfair treatment. Most North Korean BITs first set up a 'cooling-off period' before a foreign investor can commence ISDS proceedings against a host State. These BITs then continue to provide foreign investors local and/ or international remedies to resolve investment disputes in either vertical or horizontal approaches. These provisions cover the question of the 'exhaustion of local remedies', the application of 'arbitration rules', and the enforcement of arbitral awards.

\subsubsection{Cooling-Off Period}

The studied North Korean BITs contain provisions imposing a requirement in the ISDS clause about a 'cooling-off period.' ${ }^{124}$ These BITs usually set up preliminary alternatives, stating that attempts should be made to settle investment disputes through various possible approaches between the parties to the conflict, including amicable consultation, ${ }^{125}$ amicable negotiations, ${ }^{126}$ and other friendly ways. ${ }^{127}$ If the disputes cannot be thus resolved within a certain period (usually six months), the disputing party may seek local or international remedies. ${ }^{128}$

In practice, the application of the 'cooling-off period' in investment arbitration produces a great deal of uncertainty. Arbitral tribunals hold that parties are always able to enter into good faith negotiations in order to settle disputes

124 China-North Korea BIT art 9.2, Czech Republic-North Korea BIT art 8.2, DenmarkNorth Korea BIT art 9.2, Egypt-North Korea BIT art 8.3, Macedonia-North Korea BIT art 7.2, Malaysia-North Korea BIT art 7.1, Mongolia-North Korea BIT art 9.2, SingaporeNorth Korea BIT art 11.2, Slovakia-North Korea BIT art 8.2, Switzerland-North Korea BIT art 9.2, Syrian-North Korea BIT art 8.2, Thailand-North Korea BIT art 8.2.

125 Bangladesh-North Korea BIT art 7.1, Switzerland-North Korea BIT art 9.1, Syrian-North Korea BIT art 8.1, Thailand-North Korea BIT art 11.1.

126 China-North Korea BIT art 9.1, Czech Republic-North Korea BIT art 8.1; Mongolia-North Korea BIT art 9.1, Singapore-North Korea BIT art 11.1, Slovakia-North Korea BIT art 8.1.

127 Egypt-North Korea BIT art 8.1, Denmark-North Korea BIT art 9.1, Macedonia-North Korea BIT art 7.1.

128 Several BITs additionally include a specific requirement by asking for written notifications, such as a 'trigger letter', to mark the start of the consultation period. See Egypt-North Korea BIT art 8.1 and Singapore-North Korea BIT art 11.1. 
and might not need an application of the cooling-off period. ${ }^{129}$ Concerning the efficiency and cost-effectiveness of the procedure, arbitral tribunals might avoid unnecessary time being spent waiting for pre-arbitration proceedings. ${ }^{130}$ The $S G S v$ Pakistan tribunal held that arbitral tribunals generally consider the cooling-off period to be merely procedural but not mandatory. ${ }^{131}$ However, the Enronv Argentina tribunal regarded the provisions of the cooling-off period provisions as a pre-condition to arbitration, and held that a failure to comply with the cooling-off period provisions resulted in a lack of jurisdiction. ${ }^{132}$

Despite controversies, it has been argued that the question of whether or not the cooling-off period amounts to a condition precedent to arbitration depends on the terms used in the agreement. ${ }^{133}$ When the agreement stipulates that the parties 'shall' or 'must' have a cooling-off period, this becomes a pre-condition to arbitration, and when the terms 'may' and 'can' are used, the parties are not subject to legal obligations. Most existing North Korean BITs use the term 'shall', stating that any investment dispute shall, as far as possible, be settled amicably through negotiations between the parties to the dispute. ${ }^{134}$ Accordingly, foreign investors are obliged to conduct negotiations or consultations with the appropriate host State during the cooling-off period.

\subsubsection{Provisions of Remedies}

The provisions of remedies in the ISDS under the North Korean BIT s follow either a vertical or a horizontal approach (see Table 4). A vertical approach means that the ISDS mechanisms under the North Korean BITs provide only one available approach for solving investor-State disputes. Either a domestic court in the host State or an international arbitral tribunal is the sole juridical institution available for settling investment disputes. ${ }^{135}$ Considering that the vertical approach offers an exclusive option, foreign investors should be

129 Ronald S Lauderv Czech Republic, UNCITRAL, Final Award (3 September 2001) para 185, Bayindir Insaat Turizm Ticaret ve Sanayi AS v Islamic Republic of Pakistan, ICSID Case No $\mathrm{ARB} / 03 / 29$, Decision on Jurisdiction (14 November 2005) para 98.

130 Ethyl Corporation v Canada, 38 ILM 708, UNCITRAL, Decision on Jurisdiction (24June 1998) para 88; SGS v Pakistan (n 77) para 184; Bayindir v Pakistan (n 129) para 100.

$131 S G S v$ Pakistan (n 77) para 184.

132 Enron $v$ Argentina (n 87) para 88.

133 Gary Born and Marija Šćekić, 'Pre-Arbitration Procedural Requirements: "A Dismal Swamp"' in David D Caron and others (eds), Practising Virtue: Inside International Arbitration (OUP 2015) 227, 236.

134 The only exception is the North Korea-Switzerland BIT art 9, which uses the term 'will' by stating that consultations will take place between the parties concerned.

135 The Bangladesh-North Korea BIT indicates domestic courts as the exclusive forum to settle investment disputes, and art 7(2) of the Denmark-North Korea BIT provides foreign investors only one option to obtain investment protection under the ISDS. 
reminded of the pros and cons of each option. First, domestic courts can be more efficient in providing redress owing to their power and resources in issuing provisional measures and implementing judgements. However, litigation in the domestic courts of a host State is sometimes seen as lacking the objectivity desired by foreign investors, ${ }^{136}$ and being bound to apply domestic law, domestic courts might sometimes find it difficult to meet the international rules and standards. ${ }^{137}$ In terms of North Korea, the system of courts is often criticised as lacking independence, ${ }^{138}$ partly because the Supreme People's Assembly (SPA; the highest institution of State power that exercises legislative power) (or the Presidium of the SPA when the SPA is not in session) supervises the Central Court (the supreme juridical organ), while the Central Court supervises the judicial activities of all the other Courts. ${ }^{139}$ Second, by comparison, investor-State tribunals can achieve an efficient and effective settlement of disputes, fostering the international rule of law and an investment-friendly environment. ${ }^{140}$ Investor-State arbitration is the most common dispute resolution mechanism in BITs, but it is not devoid of criticism. ${ }^{141}$ Investor-State arbitration can be subject to challenges such as the legitimacy and transparency of the mechanism, the independence and impartiality of the arbitrators, and the consistency and coherence of the arbitral awards. ${ }^{142}$ Consequently, contracting States should be fully aware of the advantages and disadvantages of these two types of remedies before negotiating a vertical approach with North Korea.

It is more common that an ISDS under a North Korean BIT applies the horizontal approach, including both local and international remedies, and allows the disputed parties to freely select its favourable option to resolve disputes. One option is the local remedy, which allows a foreign investor to opt to submit its case for settlement either to the competent court or to an administrative tribunal of the host State. Another parallel option is that foreign investors can submit cases to an international arbitral tribunal. Two observations can be made based upon existing North Korean BIT s.

136 Christoph Schreuer, 'Calvo's Grandchildren: The Return of Local Remedies in Investment Arbitration' (2005) 4 Law \& Practice of Intl Courts and Tribunals 1, 2.

137 ibid.

138 Goedde ( $\mathrm{n} 17)$.

139 Constitution Law of North Korea (2019) arts 167-68.

140 Charles N Brower and Stephan W Schill, 'Is Arbitration a Threat or a Boon to the Legitimacy of International Investment Law?' (2009) 9 Chicago J Intl L 471, 497.

141 David Schneiderman, 'Judicial Politics and International Investment Arbitration: Seeking an Explanation for Conflicting Outcomes' (2010) $30 \mathrm{Nw} \mathrm{J} \mathrm{Intl} \mathrm{L} \mathrm{and} \mathrm{Bus} \mathrm{383,} 383$.

142 UNCTAD, 'IIA Issues Note International Investment Agreements' (2017) 6. 


\begin{tabular}{|c|c|c|c|c|}
\hline Type of Approach & \multicolumn{4}{|c|}{ ISDS and Respective States } \\
\hline \multirow[b]{2}{*}{ Vertical Approach } & \multicolumn{4}{|c|}{ Local Remedy Only: Bangladesh } \\
\hline & \multicolumn{4}{|c|}{$\begin{array}{l}\text { International Arbitration Only: Denmark (to the ICSID or the ad hoc } \\
\text { tribunal under the UNCITRAL rules) }\end{array}$} \\
\hline \multirow{4}{*}{$\begin{array}{l}\text { Horizontal } \\
\text { Approach }\end{array}$} & \multirow{3}{*}{ Local Remedy } & \multicolumn{3}{|c|}{ International Arbitral Tribunal } \\
\hline & & \multirow{2}{*}{$\begin{array}{l}\text { Conditional } \\
\text { Submission to the } \\
\text { ICSID }\end{array}$} & \multicolumn{2}{|l|}{ Ad Hoc Tribunal } \\
\hline & & & $\begin{array}{l}\text { UNCITRAL } \\
\text { Rules }\end{array}$ & Other Rules \\
\hline & $\begin{array}{l}\text { Czech Republic } \\
\text { China } \\
\text { Egypt } \\
\text { Macedonia } \\
\text { Malaysia } \\
\text { Mongolia } \\
\text { Singapore } \\
\text { Slovakia } \\
\text { Switzerland } \\
\text { Syrian } \\
\text { Thailand }\end{array}$ & $\begin{array}{l}\text { Czech Republic } \\
\text { - } \\
\text { Egypt } \\
\text { Macedonia } \\
\text { Malaysia } \\
\text { - } \\
\text { Singapore } \\
\text { Slovakia } \\
\text { Switzerland } \\
\text { - } \\
\text { Thailand }\end{array}$ & $\begin{array}{l}\text { Czech Republic } \\
\text { China }^{\text {a }} \\
\text { Egypt } \\
\text { Macedonia } \\
\text { Malaysia } \\
\text { Mongolia } \\
\text { Singapore } \\
\text { Slovakia } \\
\text { Switzerland } \\
\text { Syrian } \\
\text { Thailand }\end{array}$ & $\begin{array}{l}- \\
- \\
- \\
- \\
- \\
- \\
\text { Singapore } \\
- \\
\text { Switzerland } \\
- \\
-\end{array}$ \\
\hline
\end{tabular}

a Take the Arbitration Rules of the UNCTRAL as a guidance

b Switzerland-North Korea BIT art 9.2 states that the Additional Facility Rules for the Administration of Proceedings by the Secretariat of the ICSID might also apply on the basis of the choice of the disputed parties.

SOURCE: AUTHOR COMPILATION BASED ON STUDIED BITS

First, some North Korean BITs allow investment disputes to be submitted to the International Centre for Settlement of Investment Disputes (ICSID) if both contracting states are party to the Convention on the Settlement of Investment Disputes between States and Nationals of Other States (ICSID Convention). ${ }^{143}$ This provision adopts the model clause of ICSID about requests for arbitration. ${ }^{144}$ The option of submitting the claim to ICSID is conditional, as North Korea is still not a member of ICSID. However, it shows that North Korea might be open to joining the ICSID Convention. Yet, before this materialises,

143 North Korean BIT s with Czech Republic, Egypt, Macedonia, Malaysia, Singapore, Slovakia, Switzerland, and Thailand. The Convention on the Settlement of Investment Disputes Between States and Nationals of Other States (entered into force on 14 October 1966) (ICSID Convention).

144 ICSID, 'Model Clauses' <http://icsidfiles.worldbank.org/icsid/icsid/staticfiles/model -clauses-en/7.htm\#a > accessed 17 February 2021. 
another international arbitration model is more practical to settle investment disputes with North Korea.

Second, all North Korean BITs except the Bangladesh-North Korea BIT allow disputes to be settled by an ad hoc arbitral tribunal. ${ }^{145}$ These BIT s usually request the ad hoc arbitral tribunal to be constituted under the UNCITRAL Arbitration Rules. ${ }^{146}$ In addition to this, the Singapore-North Korea BIT also allows foreign investors to submit their investment arbitration claims to any other applicable arbitral institution or under any other arbitral rules, subject to party autonomy. Similarly, the Switzerland-North Korea BIT allows the arbitral proceedings administered under the additional ICSID facility rules by the secretariat of the ICSID. In this way, although North Korea is not a member of the ICSID Convention, the additional ICSID facility rules can still apply.

\subsubsection{Exhaustion of Local Remedies}

The requirement about the exhaustion of local remedies means that a foreign national who is allegedly harmed by the State must first seek redress for the alleged damage through the administrative and judicial system of that State, until a final decision has been rendered, before it can initiate international proceedings directly against the State. ${ }^{147}$ For example, Article 9 of the ChinaNorth Korea BIT requires the exhaustion of local remedies by stating that:

the Contracting Party involved in the dispute may require the investor concerned to exhaust the domestic administrative review procedure specified by the laws and regulations of that Contracting Party before submission of the dispute to the above-mentioned arbitration procedure.

ISDS practice indicates that the requirement for the exhaustion of local remedies is waived unless a treaty has expressly required it. ${ }^{148}$ In ICSID arbitrations, according to Article 26 of the ICSID Convention, disputing parties consenting to arbitration are simultaneously deemed to consent to the exclusion of any other remedy unless otherwise stated. In non-ICSID arbitrations, arbitral tribunals hold that the BITs grant foreign investors direct access to

\footnotetext{
145 North Korean BITs with Czech Republic, China, Denmark, Egypt, Macedonia, Malaysia, Mongolia, Singapore, Slovakia, Switzerland, Syrian, and Thailand.

146 The China-North Korea BIT is one exception. It requests the ad hoc tribunal shall be constituted under the art 9.4 of the BIT, while the tribunal shall determine its own procedure or take the UNCITRAL Arbitration Rules as a guidance to determine the procedure.

147 Martin Dietrich Brauch, 'Exhaustion of Local Remedies in International Investment Law' (January 2017) IISD Best Practices Series 2.

148 ibid 14.
} 
international arbitration without requiring the exhaustion of local remedies. ${ }^{149}$ Consequently, under the North Korean BIT s, if the contracting States prefer to have the exhaustion of local remedies as a pre-condition to access to international investment arbitration, this preference should be expressly stipulated in the respective BIT.

\subsubsection{Arbitration Rules}

All the North Korean BITs were concluded before 2009, but the UNCITRAL Rules were modified and revised in 2010 and 2013 after first announced in 1976. In particular, the 2013 revision incorporated the UNCITRAL Rules on Transparency for Treaty-Based Investor-State Arbitration. ${ }^{150}$ At the time of the negotiation and conclusion of all the North Korean BITs, State parties were only aware of the 1976 rules but not the subsequent revised versions. According to the 1976 rules, if the parties to a contract have agreed in writing that disputes arising from that contract shall be referred to arbitration under the UNCITRAL Arbitration Rules, such disputes shall be settled under the current version of the rules subject to any modification that the parties may agree in writing. ${ }^{151}$ Similar provisions are also found in the 2010 and 2013 versions of the rules. ${ }^{152}$ This makes it clear that unless the interested States make a separate agreement that modifies the current version of the rules, the latter should apply. Therefore, most of existing BIT s in this study should apply the latest version of UNCITRAL Rules unless the party States agree otherwise. ${ }^{153}$ Turning to future BITs, contracting States should be reminded that the newly revised rules will apply unless the parties opt for the old rules. Different arbitral rules may grant different rights to the parties to a dispute, and therefore,

149 Waste Management, Inc v United Mexican States, ICSID Case No ARB (AF)/oo/3, Award (30 April 2004) paras 116, 133. CME Czech Republic BVv Czech Republic, UNCITRAL, Legal Opinion Prepared by Christoph Schreuer and August Reinish (22 May 2002) paras 245-47.

150 The 2013 revision adds art 1.4 into the 2010 revision of the UNCITRAL Rules. The other provisions remain the same.

$151 \quad 1976$ UNCITRAL Rules art 1.

152 The 2013 and 2010 UNCITRAL Rules state that 'the parties to an arbitration agreement concluded after 15 August 2010 shall be presumed to have referred to the Rules in effect on the date of commencement of the arbitration unless the parties have agreed to apply a particular version of the Rules'. See 2010 UNCITRAL Rules art 1 and 2013 UNCITRAL Rules art 1.

153 One exception is that the newly revised rules would not apply 'where the arbitration agreement has been concluded by accepting after 15 August 2010 an offer made before that date'. Consequently, according to this provision, as the BIT between the Syrian Arab Republic and North Korea was signed on 14 May 2006 and the BIT between Bangladesh and North Korea was signed on 21 June 1999, and both have not yet been ratified by both States, if the BITs enter into force later on, the 1976 UNCITRAL rules would still apply unless both States agree on another version of the rules. 
foreign investors are recommended to take careful account of specific arbitration rules that they are eligible to apply.

\subsubsection{Enforcement of ISDS Awards}

The enforcement of ISDS awards is another concern to which foreign investors might draw critical attention. The parties to a dispute are bound by the arbitral award and have an obligation to enforce the award. In an ICSID arbitration, the contracting State shall recognise an award rendered according to the ICSID Convention as binding and enforce the pecuniary obligations imposed by that award within its territories as if it were a final judgment of a court in that State. ${ }^{154}$ The recognition and enforcement of these arbitral awards might be sought in the host State, in the investor's home State, or in any other State that is a party to the ICSID Convention, subject to the availability of suitable assets. ${ }^{155}$ The execution of the award is governed by the laws on the execution of judgements in the State in which enforcement is sought. As North Korea is not a member of ICSID, foreign investors cannot yet enforce ISDS awards by making use of the ICSID mechanism.

The enforcement of non-ICSID arbitral awards might rely on the national law of the place of enforcement, and the New York Convention on the Recognition and Enforcement of Foreign Arbitral Awards where it is applicable. ${ }^{156}$ However, North Korea is not a party to the New York Convention either. Therefore, when a foreign investor wins a case on the basis of a North Korean BIT, and wishes to enforce the award in North Korea, the national law of the place where the enforcement is sought, namely the domestic law of North Korea, applies.

Another available method for a foreign investor to enforce an award is through bilateral cooperation or agreements regarding the enforcement of arbitral awards. A comprehensive provision in relation to enforcement under the BIT would help foreign investors secure the execution of arbitral awards. For instance, the Singapore-North Korea BIT provides that 'each Contracting Party shall ensure the recognition and enforcement of the award in accordance with its relevant laws and regulations.' ${ }^{\prime 57}$ This straightforward provision ensures that the contracting States have a responsibility to enforce the awards, while foreign investors have a clear legal basis to ask for execution.

\footnotetext{
154 ICSID Convention (n 143) art 54.

155 Dolzer and Schreuer (n 66) 310.

156 ibid. The New York Arbitration Convention on the Recognition and Enforcement of Foreign Arbitral Awards, (signed on 10 June 1958, entered into force on 7 June 1959) (New York Convention) 330 UNTS 38 .

157 Singapore-North Korea BIT art 4.
} 
Since North Korea is neither a party to the ICSID Convention nor the New York Convention, foreign investors can only enforce their awards through the domestic law of North Korea. To provide additional guarantee of enforcement for their investors, a contracting State may consider inputting in its future BIT with North Korea an enforcement provision similar to the one used in the Singapore-North Korea BIT.

Just as Tutankhamun, an Egyptian pharaoh, said, 'I have seen yesterday; I know tomorrow', 158 the preceding analysis of the existing BITs can entail several implications for potential BITs with North Korea in the future. In particular, the first to fourth implications concern the clauses of 'territorial scope', 'substantive protection', 'expropriation and compensation' and the SSDS, respectively. The fifth to eighth implications relate to different provisions of the ISDS clause, including the 'cooling-off period' provision, the 'exhaustion of local remedy' provision, the 'arbitral rules' provision, and the 'recognition and enforcement' provision.

First, with respect to the 'territorial scope' clause in the future BITs, this research suggests that the future BIT s adopt a similar 'territorial scope' clause contained in the existing BITs but add a specific reference to include marine areas claimed by North Korea such as the Yellow Sea. The 'territorial scope' clause can thus be framed as follows: North Korea's territory over which a BIT shall apply include the territorial land, territorial sea, exclusive economic zone and continental shelf over which it exercises or claims to exercise sovereign rights or jurisdiction in accordance with its national law and international law. 159

Second, concerning the 'expropriation and compensation' clause, the Panmunjom Declaration signed by North Korea and South Korea does not have the effect of formally ending the Korean War. Hence, if the investments of foreign investors suffer losses or damage on the territories of North Korea, the risk remains that North Korea might use war as a justification to exempt itself from paying compensation to these investors to the extent that it does not grant any treatment to any third State or its own investors. Moreover, since North Korea is not a party to MIGA, foreign investment in the territory of North Korea are not eligible to obtain the protection from the MIGA regime. Therefore, this

\footnotetext{
158 Juliette Desplat, 'I Have Seen Yesterday, I Know Tomorrow' (The National Archives, 7 April 2014) <https://blog.nationalarchives.gov.uk/seen-yesterday-know-tomorrow/> accessed 17 February 2021.

159 Singapore-North Korea BIT art 1.4.
} 
research recommends that before a peace treaty comes into existence and takes effect, for risk prevention, the contracting States may stipulate in their BIT s that the Korean war cannot be used as a justification to evade the payment of compensation.

Third, the existing BIT s contain various substantive protection provisions, including FPS, FET, the umbrella clause, NT and MFN, showing the open attitude of North Korea in embracing diverse legal protection for foreign investors. To establish a comprehensive protective environment for foreign investment, countries in their negotiation with North Korea are recommended to consider the inclusion of both FPS and FET in BIT provisions, phrasing the umbrella clause in broad terms to expand the scope of protection, and an express mention about which stages of foreign investment are covered by NT and MFN standards.

Fourth, for the design of the SSDS clause, some of the existing BITs prescribes a two-step procedure, which allows a State party to initiate arbitration or litigation proceedings if a dispute cannot be settled by negotiation or consultation. If a two-step procedure is intended, for the sake of clarity and certainty, this research recommends the contracting States to set forth a cooling-off period in their BITs, such as three or six months. Yet, even if a cooling-off period is specified, foreign investors should be reminded that when an inter-State dispute is submitted to a court or tribunal according to the BIT concerned, preceding international jurisprudence tends to suggest that the court or tribunal would consider the lack of a cooling-off period a mere defect of form that cannot hamper its jurisdiction over the case.

Fifth, a 'cooling-off period' provision may also be contained in the ISDS clause. However, whether this provision prohibits the parties from submitting a case for adjudication before the 'cooling-off period' passes remain highly disputable in international jurisprudence. After analysis, this research argues that if the provision sets forth that parties 'shall' or 'must', instead of 'may' or 'can', have a cooling-off period, then the exhaustion of such a cooling-off period is a prerequisite for the initiation of relevant arbitration or litigation proceedings. Accordingly, to ensure clarity and predictability, this research recommends the contracting States use the wording such as 'shall' or 'must' for the 'cooling-off period' provision in the ISDS clause.

Sixth, States might insert an 'exhaustion of local remedy' provision in the ISDS clause. For instance, the China-North Korea BIT requires the exhaustion of the domestic administrative review procedure before an investor from either of these two States can submit a dispute to the ad hoc arbitration provided in this BIT. ${ }^{160}$ Notably, the international judicial practice widely rec-

16o China-North Korea BIT art 9. 
ognises that unless otherwise provided, BITs should grant foreign investors direct access to international remedies without requiring the exhaustion of local remedies. Therefore, this research recommends States that favour the application of the exhaustion of local remedies to explicitly insert an 'exhaustion of local remedy' provision in the ISDS clause. Otherwise, the absence of this provision entails that the exhaustion of local remedies is not required.

Seventh, about the 'arbitral rules' provision of the ISDS clause, the existing BITs have selected either the ICSID Rules or the UNCITRAL Rules. For future BITs, it is important to realise that the selected arbitral rules might change over time. For instance, ICSID is currently in the process of amending its rules and regulations. ${ }^{161}$ Hence, if the contracting State parties to the new BITs do not intend to apply any revised version of the selected arbitral rules automatically, they shall state this intent explicitly in the BITs.

Eighth, considering that North Korea is not a member or party to the ICSID or the New York Conventions, the recognition and enforcement of the ISDS awards as a result of the judicial remedies provided by the BITs are not secured. Therefore, this research suggests the contracting States incorporate a 'recognition and enforcement' provision that obliges them to recognise and enforcement relevant ISDS awards. A preceding example of such a provision is the Singapore-North Korea BIT, which provides that ' $[\mathrm{e}] \mathrm{ach}$ Contracting Party shall ensure the recognition and enforcement of the [arbitral] award in accordance with its relevant laws and regulations.' ${ }^{\prime 62}$

To conclude, North Korea is a promising land but at the same time a risky land for foreign investment. By conducting a systemic and comparative analysis of the existing BIT s signed by North Korea in the Kim Jong-il era, this article has put forward eight tips that can better prepare those daredevils who are interested in seizing the forthcoming opportunity to invest in this last economic frontier in Northeast Asia.

\section{Biographical Note}

Dr. Xuechan Ma completed her PhD at Leiden University and is currently a climate change specialist at the Food and Agriculture Organisation of the United Nations. Dr. Anran Zhang (corresponding author) completed his PhD at Erasmus University Rotterdam.

161 ICSID, 'About the ICSID Rule Amendments' <https://icsid.worldbank.org/resources/ rules-and-regulations/amendments/about $>$.

162 Singapore-North Korea BIT art 11.4. 